\title{
An Investigation of the Effectiveness of Developmental/Remedial Education at West Virginia Institutions of Higher Education
}

Blake J. Renner

West Virginia University

Follow this and additional works at: https://researchrepository.wvu.edu/etd

\section{Recommended Citation}

Renner, Blake J., "An Investigation of the Effectiveness of Developmental/Remedial Education at West Virginia Institutions of Higher Education" (2011). Graduate Theses, Dissertations, and Problem Reports. 3042.

https://researchrepository.wvu.edu/etd/3042

This Dissertation is protected by copyright and/or related rights. It has been brought to you by the The Research Repository @ WVU with permission from the rights-holder(s). You are free to use this Dissertation in any way that is permitted by the copyright and related rights legislation that applies to your use. For other uses you must obtain permission from the rights-holder(s) directly, unless additional rights are indicated by a Creative Commons license in the record and/ or on the work itself. This Dissertation has been accepted for inclusion in WVU Graduate Theses, Dissertations, and Problem Reports collection by an authorized administrator of The Research Repository @ WVU.

For more information, please contact researchrepository@mail.wvu.edu. 
An Investigation of the Effectiveness of Developmental/Remedial Education at West Virginia Institutions of Higher Education

By:

Blake J. Renner

Dissertation submitted to the College of Human Resources and Education at West Virginia University

in partial fulfillment of the requirements

for the degree of

Doctor of Education

in

Educational Leadership Studies

Approved by

Ernest Goeres, Ph.D., Committee Chair

Patricia Haught, Ed.D.

Edward Jacobs, Ph.D.

Paul Chapman, Ph.D.

Angela Bell, Ph.D.

Department of Educational Leadership Studies

Morgantown, WV

2011 


\begin{abstract}
An Investigation of the Effectiveness of Developmental/Remedial Education at West Virginia Institutions of Higher Education
\end{abstract}

by Blake J. Renner

Underprepared college students are a continuing challenge for higher education institutions. Many students arrive at institutions of higher education with weak academic skills and are unable to do college-level school work. As a result, developmental education programs are required to address these inadequacies in student preparation. The purpose of this study is to assess the effectiveness of these developmental education programs. The goal is to determine the relationship between developmental education programs in West Virginia four-year higher education institutions and the success of the students in these programs as measured by degree completion and the terms to degree required to complete the degree program.

The population for this study was 17,168 recent high school graduates who were full-time, firstyear students at the ten public four-year public institutions in West Virginia in the fall terms of 2002 and 2003. For the study the population $(\mathrm{N}=17,168)$ was divided into two groups, those students who took developmental education (4,594 students) and those students who did not take developmental education (12,574 students). Variables predicted to influence the likelihood of graduation and the time to degree were included in the conceptual areas of student background, academic preparation, institutional factors, and financial aid received.

A quasi-experimental research technique, coarsened exact matching, was used to assess differences in outcomes for students who participated in developmental education while controlling for selection bias. The study found that student who took developmental education courses were less likely to graduate than similar student who did not take developmental education. Also, students that took developmental education courses took longer to graduate than similar student who did not have to take developmental education. These findings echo those of Attewell, Lavin, Domina, and Levey (2006), Martorell and McFarlin (2007), and Calcagno and Long (2008) in that students who take any developmental education courses, even if they passed those courses, were less likely to graduate within six years and would require more time in their pursuit of degree attainment. 


\section{ACKNOWLEDGEMENTS}

I owe my deepest gratitude to the many people that have assisted me in getting to this point in my educational career. I am so thankful for all of their support and encouragement that was essential to the completion of my dissertation.

I would first like to thank my family; Melinda (Mom), the late John (Dad), Kelly, Tyler, and Prince. Without their love, patience, and encouragement through this process I know I would not be to this point. Words cannot express how much I appreciate all you have done.

I would like to thank my committee chair, Dr. Ernest Goeres, for his time, reassurance, and assistance during my entire program of study. I consider myself lucky to have a mentor that always took the time to talk and assist with any of the problems that I was experiencing. I consider Dr. G to be a friend and he is someone that I would like to model myself after as I become an educator.

I would also like to thank Dr. Angie Bell for her help with the statistical analyses and writing of this study. Dr. Bell has shown me many of the facets that go into becoming a researcher and has taught me the application of different research techniques that were implemented in this dissertation. I am truly grateful for her willingness to help and kindness and hope that one day we can again work together on another project.

Thank you to Dr. Paul Chapman for his encouragement and assistance. The suggestions and questions he raised have been tremendously helpful in allowing me consider the bigger picture and the implications of my research.

I would also like to thank Dr. Ed Jacobs who has pushed me to become a better student and has taught me many valuable tools that are not only applicable to counseling but also to administration duties. His comments have helped to enrich my ideas and concepts for this study.

Also, thank you to Dr. Patricia Haught for all the encouragement and support. If not for the work she is doing at West Virginia University and allowing me to work with her teaching developmental education, I would not have researched this topic. Her feedback was very helpful and provided me with good insight into developmental education.

Finally, thank you to the West Virginia Higher Education Policy Commission. 


\section{Table of Contents}

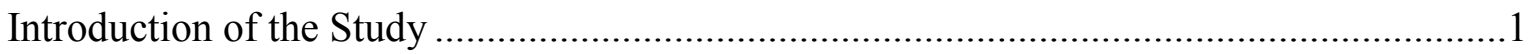

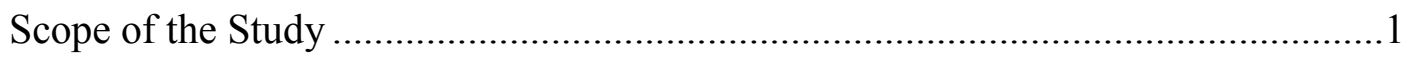

Statement of the Problem......................................................................................

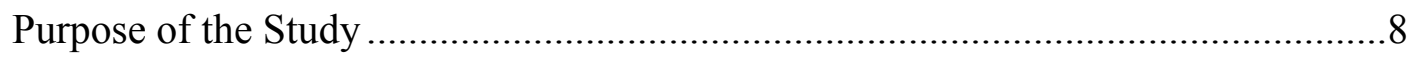

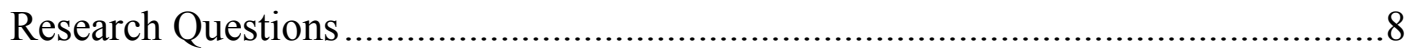

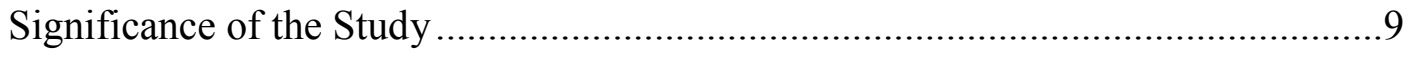

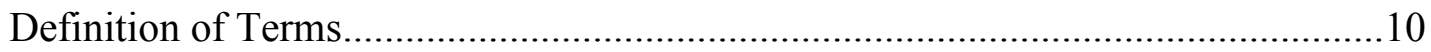

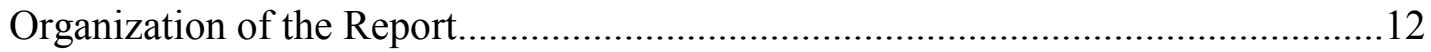

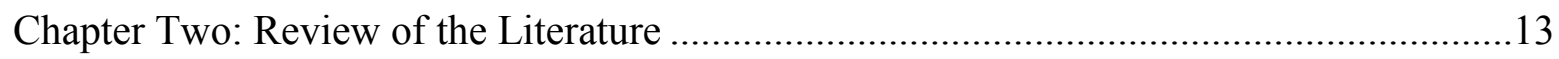

National and State Assessments of Education ......................................................13

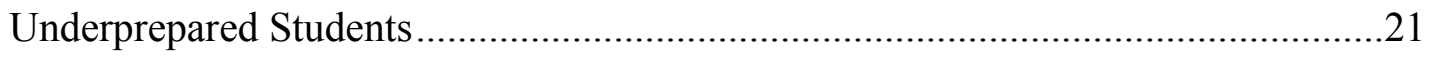

Cost of Developmental/Remedial Education.............................................................

Effectiveness of Developmental/Remedial Education...............................................35

West Virginia Higher Education Policy Commission's Standards .............................44

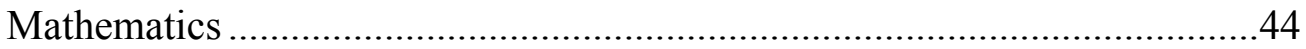

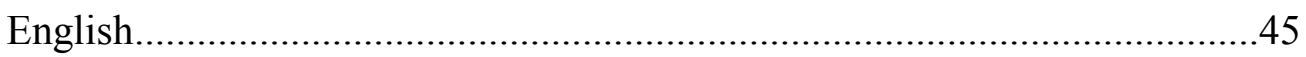

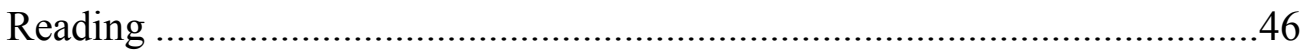

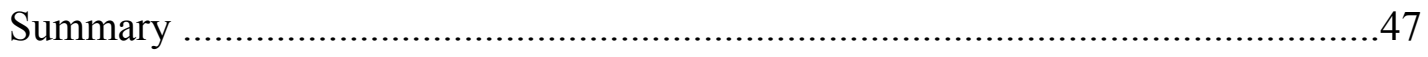

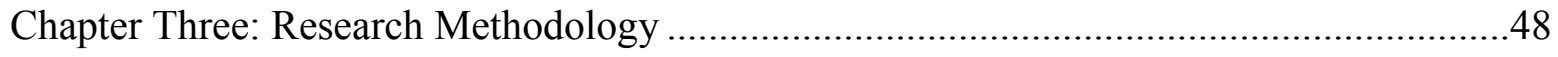

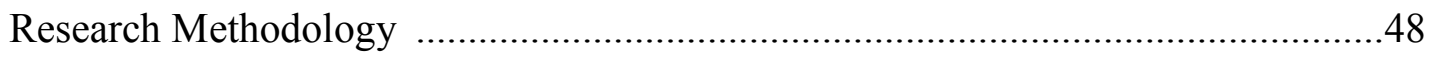

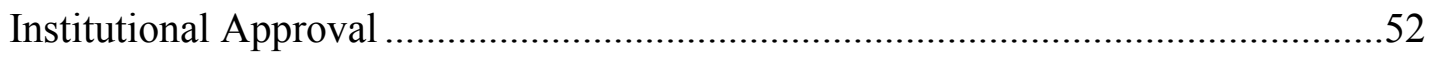

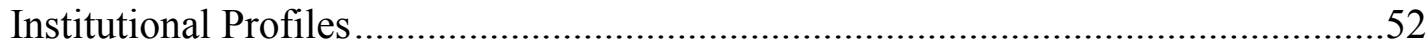


Population .54

Data Coding

Student Demographic Information. .55

Academic Information .55

Developmental Course Information. .56

Data Analysis . 56

Limitations of the Study 59

Summary .59

Chapter Four: Findings 61

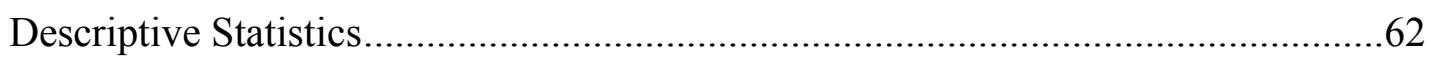

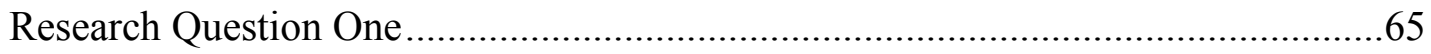

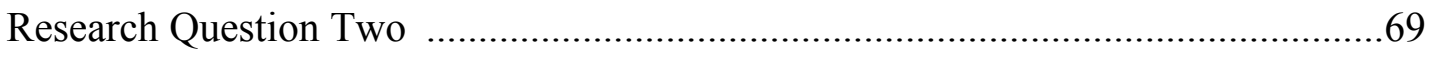

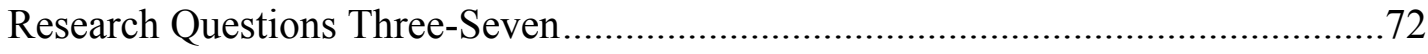

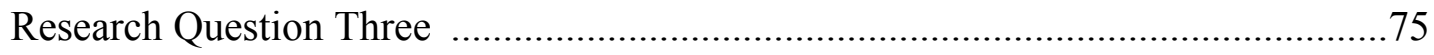

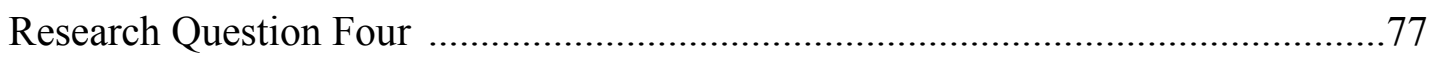

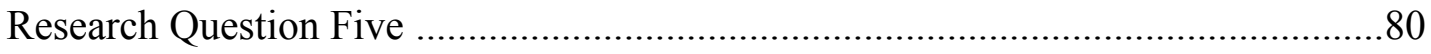

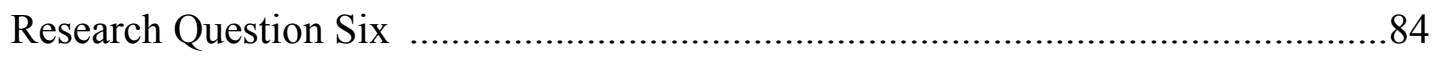

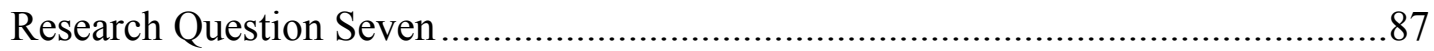

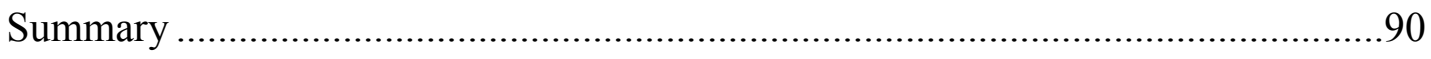

Chapter Five: Summary, Conclusions, and Recommendations ....................................92

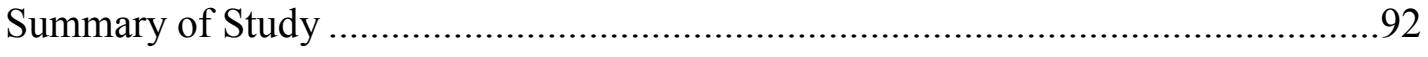

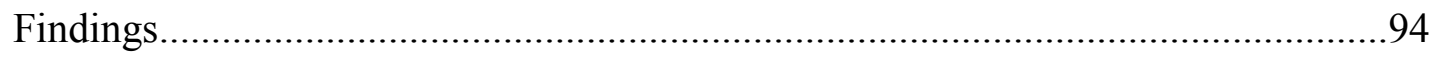

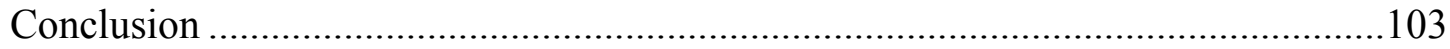




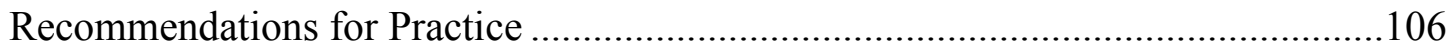

Recommendations for Future Research ..............................................................109

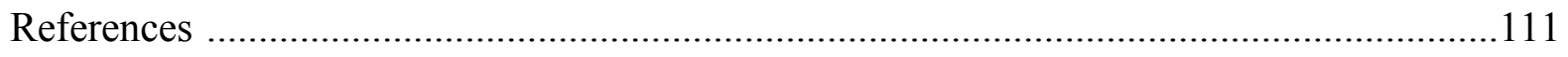

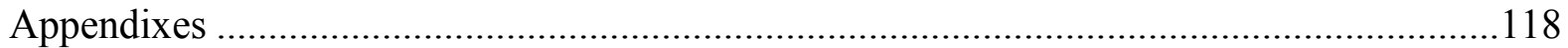

Appendix A: Data Agreement WVHEPC...............................................................118

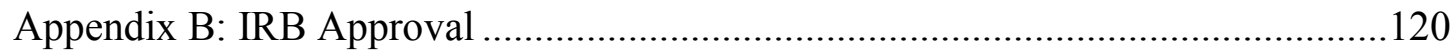




\section{Lists of Tables}

Table 1 Institutions' Selection Method for Remedial Education 30

Table 2 Percent of Institutions Using Placement Tests for All Students for

Developmental Placement by Institutional Type.

Table 3 Institutional Profiles

Table 4 Analysis Techniques for Research Questions...... 57

Table 5 Race .62

Table 6 Sex

Table 7 Institution Attended. 63

Table 8 Other Characterizes. .64

Table 9 High School Grade Point Average and ACT Scores..... 64

Table 10 Race of Students that Took Developmental Education 65

Table 11 Sex of Students that Took Developmental Education .66

Table 12 Percentage of Students that Took Developmental Education by Institution

Table 13 Other Characteristics of Students that Took Developmental Education

Table 14 Comparison of Students that Took and Did Not Take Developmental

Education High School Grade Point Average and ACT Scores. .68

Table 15 Comparison of Descriptive Information .69

Table 16 Number of Developmental Courses Taken ........................................................ 70

Table 17 Students that Took Developmental Education Subject Area ……..........................71

Table 18 Percentage of Students Who Took a Developmental Subject and Also

Needed To Take a Different Developmental Subject .72

Table 19 Variables Included in the Study by Conceptual Blocks. 74 
Table 20 Likelihood of Graduation for Students Who Did and Did Not Take

Developmental Education

76

Table 21 Likelihood of Graduation for Students Who Took and Passed Developmental

Courses and for Students that Did Not Take Developmental Courses. 79

Table 22 Relationship Between the Subject of Developmental Course Taken and

the Likelihood of Graduation

Table 23 Time to Degree for Students Who Did Take and Did Not Take

Developmental Courses.

Table 24 Time to Degree for Students Who Took and Passed Developmental

Courses and for Students that Did Not Take Developmental Courses. 


\section{Chapter One:}

\section{Introduction of the Study}

\section{Scope of the Study}

The main focus of higher education institutions is to prepare students for a future career in a learned profession. Most aspects of the current academic system in place at American institutions of higher education can be traced to those institutions founded during the colonial era (Cohen, 1998). Over the past four centuries there have been numerous changes that have been implemented at institutions of higher education (Bok, 2003). However, one area that has been a constant at higher education institutions is the need for developmental or remedial education. The National Center for Educational Statistics (1996) of the United States Department of Education reported that " 41 percent of first-time community college freshmen and almost 30 percent of all first-time college freshmen, enroll in one or more developmental courses" (p. 83). This number is even higher is some states as Parks (2001) reported that "According to the West Virginia Higher Education Report Card 2000, approximately one-half of all college freshmen in our state require some sort of developmental education service (p. 64)” (p. 5).

Students, past and present, have entered colleges and universities unprepared to handle the standards that were required of them to be successful (Mulvey, 2008). These underprepared students require additional assistance to gain that success at the college level.

Developmental/remedial educational programs have bridged this gap to assist students who are not prepared to meet college standards. "Developmental education refers to a broad range of courses and services organized and delivered in an effort to help retain students and ensure the successful completion of their postsecondary education goals" (Boylan \& Bonham, 2007, p. 2). Developmental/remedial programs accommodate differences in students' development by 
allowing them to acquire skills and abilities that they did not obtain in their secondary education. Developmental education is an umbrella term that encompasses a variety of courses and services offered to underprepared students.

Developmental/remedial education has its roots in colonial colleges. The purposes of founding these colonial colleges were to educate young people by teaching them character formation, preparation for careers, networking, language, manners, and religion. Most of the learned books and the lectures that were taught in these colleges were in Latin (Boylan \& White, 1987). During this time very few children attended or had access to a school, which meant that parents were responsible for their children's schooling (Stephens, 2001). Many of these students entered the colonial colleges too underprepared in Latin studies to be successful at the college level. As a result, colonial colleges provided tutors in Latin for the incoming students (Boylan \& White, 1987). The provision of these services is regarded as the first developmental educational programs implemented in higher education in the United States.

During the $19^{\text {th }}$ century, colleges were largely self-sustaining operations primarily funded by private donations and students fees (Boylan \& White, 1987). During this time colleges became increasingly more costly for students, which meant that only the most privileged families could afford to send their sons to college (Stephens, 2001). Indeed, some wealthy families sent their sons to college even though they did not meet the entrance requirements set forth by the colleges. During this time, college curriculum and entrance requirements steadily increased and more students arrived at college with insufficient academic preparation (Stephens). With increased enrollment and the increased numbers of students who were underprepared for college, the demand for tutors to teach developmental/remedial courses grew dramatically. 
This problem was so pronounced that the University of Wisconsin established the first preparatory department in 1849 (Brier, 1984). The focus of this department was to provide developmental education courses that focused on reading, writing, and arithmetic for students who were underprepared in these areas (Boylan \& White, 1987). By 1889, 80 percent of colleges provided some form of developmental educational programs for their students (Boylan $\&$ White).

Also during this time, the Morrill Act was signed by President Abraham Lincoln on July 2, 1862. The Morrill Act was a grant that provided each state with 30,000 acres of public land for each Senator and Representative it had in Congress. The land was then to be sold and the money from the sale of the land was to be put in an endowment fund, which would provide support for at least one college in each of the states. Each of these colleges was required to focus on teaching curriculum related to agriculture and the mechanic arts while still incorporating the core curriculum in place at college and university campuses (Lucas, 2006). The purpose of the Morrill Act was not only to expand the endowments of American colleges and universities; it was also attempting to make higher education accessible for everyone. This expansion in student enrollments along with the growth that took place at women's colleges and colleges for AfricanAmerican students led to an increased need for developmental education. Women's colleges often needed to provide developmental programs to their students because women were not afforded the opportunity to obtain an adequate secondary education (Boylan \& White, 1987). Colleges for African-American students depended heavily on developmental education because prior to 1860 a structured primary or secondary educational program was not available for African-Americans. Many of the students were former slaves who were not permitted to learn 
how to read and write. As a result, a primary focus of these colleges was to incorporate developmental education as part of the core curriculum (Jones \& Richards-Smith, 1987). By the early $20^{\text {th }}$ century a new movement occurred in developmental education when junior colleges became more prominent in American higher education. Colleges and universities were becoming more financially stable, allowing them to become more focused on the quality of the students and less focused on the quantity of the students (Boylan, 1988). Colleges and universities began phasing out developmental education because junior colleges provided students with an alternative education that was a mixture of the first two years of college programs and developmental educational courses.

The implementation of the Servicemen's Readjustment Act, commonly referred to as the G.I. Bill, signed on June 22, 1944, again changed the landscape of developmental education at institutions of higher education. The G.I. Bill allowed men and women who served in the United States Armed Forces the opportunity to attend institutions of higher education. Veterans were offered four years of government funding in the areas of housing loans, unemployment compensation, and educational training. The impact the G.I Bill had on higher education was that enrollment in higher education doubled. For the first time college campuses were not only comprised of eighteen to twenty-three year olds, but non-traditional students, as well (Lucas, 2006). Colleges and universities worked to accommodate the learning needs of the veterans by offering different developmental programs (Boylan, 1988).

Several other trends broadened the reach of higher education in the last half of the $20^{\text {th }}$ century. Access to American higher educational institutions increased throughout the 1950's and 1960s due to the civil rights movement (Stephens, 2001). In the 1960's and1970's the baby boom population began to attend college and institutions of higher education were again 
inundated with large numbers of students. The 1970's also brought about the concept of open admissions where focus was placed on providing opportunities to students who were poor, disadvantaged, non-traditional, had health issues, or had learning disabilities (Boylan, 1988). Many of these students were first-generation college students and presented new issues for institutions of higher education to deal with. With each new group attending college the need for developmental education increased.

The United States Department of Education, specifically the National Center for Educational Statistics (NCES), published a report in 1984 looking at developmental education. The significance of this report was that for first time the U.S. Department of Education acknowledged developmental education as a part of higher education that needed to be researched (Boylan \& Bonham, 2007). The NCES has published three reports subsequent to its original report in 1984. These four reports show that the percentages of all students entering institutions of higher education who needed remediation has remained fairly consistent at around 28 percent. The U.S. Department of Education annual report entitled "The Condition of Education" also includes specific data on developmental education (Boylan \& Bonham, 2007).

In the past thirty years several events have lead to the legitimacy of developmental education as a discipline and as a profession. The first of these is the first doctoral program in developmental education at Grambling State University in 1986 (Boylan \& Bonham, 2007). In 1992 the first National Conference in Developmental Education was held and has led to improved research based practices within the field. In 1996 the American Council of Developmental Education Association (ACDEA) was established to promote collaboration of research ideas between professionals within the field. More recently, in 2007, states like Texas, Kentucky, and California developed programs to improve their developmental educational 
programs. Boylan and Bonham (2007) reported that, "According to the National Center for Education Statistics (2003), 99 percent of community colleges and about 70 percent of universities offered developmental courses."

Students entering colleges and universities underprepared to face the rigors of educational programs were made more evident in 2006 with the U.S. government's report, $A$ Test of Leadership: Charting the Future of Higher Education, also referred to as The Spellings Report. This report, with respect to learning outcomes, emphasized that, American high school students were not meeting the standards set forth by the educational systems in place in other countries and were entering college underprepared (Spelling, 2006). This problem continues to be a national issue and is affecting each state to some extent. For example, a study conducted by the Editorial Projects in Education Research Center (2010) compared West Virginia primary and secondary students' performance academically to other states' students' performance academically. The study found that West Virginia students ranked below the national average in most of the academic categories, which included The Chance-for-Success Index, The Math Progress Index, and the K-12 Achievement Index, and finished in the both bottom half for student graduation. The study's overall assessment placed West Virginia along with Mississippi, Alabama, and the District of Columbia, as the only four district/states to receive a failing grade. These shortcomings at the primary and secondary level create the need for developmental education courses at institutions of higher education

Developmental education programs have been created to address this very need at institutions of higher education. Throughout the past thirty years legislators have placed more emphasis on developmental education and the importance of its existence in higher education (Boylan \& Bonham, 2007). As a result of underprepared students continuing to enroll at 
colleges and universities, developmental education continues to play an important role in American higher education.

\section{Statement of the Problem}

Underprepared college students are a continuing challenge for higher education institutions. As a result of open enrollment policies, inadequate academic preparation for college does not prevent students from attending a college or university. Levine and Cureton (1998), as cited in Mulvey (2008), discussed how today's students were attending college with even less preparation than in previous years. When institutions of higher education accept these students they also make a commitment to these students' educational success. By making this commitment, institutions need to provide students with the support that they require to be successful and graduate.

To address the needs of the underprepared student, institutions have implemented developmental education programs. Developmental education programs include remedial education courses, student advising, workshops, learning laboratories, individualized instructions, and both group and individual tutoring (Boylan \& Bonham, 2007). Many researchers argue that developmental education is essential for students lacking the required skills to succeed in higher education and provides the opportunity for those students to improve their own lives and the lives of their families (Boylan, 1999, McCabe, 2000, McCabe \& Day, 1998).

According to the NCES (2003), around 28 percent of all college students require some form of developmental education. In West Virginia, Parks (2001) reported "According to the West Virginia Higher Education Report Card 2000, approximately one-half of all college freshmen in our state require some sort of developmental education service (p. 64)." Boylan and 
Bonham (2007) reported that, according to the NCES (2003), 99 percent of community colleges and about 70 percent of universities offered developmental courses in the 2003 academic year. In response to these reports, awareness of developmental education and its role at institutions of higher education has increased.

As developmental education becomes a larger concern for institutions of higher education, research must be conducted to assess its effectiveness. Grubb (2001) points out that few evaluations of remedial programs have been conducted. Evaluation of these programs is essential to assess if developmental education is the solution to the problem facing institutions of higher education as they admit underprepared students. "Meta-analytical studies and extensive critical reviews of the literature of developmental education are few in number" (Preuss, 2008, p. 12).

\section{Purpose of the Study}

The purpose of the study is to determine the relationship between developmental education programs in West Virginia four-year higher education institutions and the success of the students in these programs as measured by degree completion and the number of years required to complete the degree program. This dissertation focuses on developmental education at West Virginia institutions of higher education, its effectiveness in leading to academic success and graduation, and any implications in terms of time to degree completion.

To accomplish this goal, the following research questions were developed for this dissertation.

\section{Research Questions}

1. What is the demographic makeup and academic preparation level of first-year students taking remedial courses at public four-year institutions compared with students who do not take developmental courses? 
2. Among the students required to take developmental education courses, what is the proportion of students who took different numbers of developmental classes and of students in the subject areas of mathematics, writing, reading, English, and basic skills?

3. Does the likelihood of graduation differ between students who took developmental education courses and similar students who did not take any developmental courses?

4. Does the likelihood of graduation differ between students who took and passed developmental education courses and similar students who did not take any developmental courses?

5. What is the relationship between the subject of developmental courses taken and the likelihood of graduation?

6. Does time to degree differ between students who took developmental education courses and similar students who did not take any developmental courses?

7. Does time to degree differ between students who took and passed developmental education courses and similar students who did not take any developmental courses?

\section{Significance of the Study}

According to Bettinger and Long (2005) "Despite the extensive use of remedial courses to address academic deficiencies, little is known about their effects on subsequent student performance in college" (p. 2). This study will begin to answer the question of the effectiveness of developmental and remedial educational programs at West Virginia institutions of higher education. This is particularly important because one half of all college freshmen require some sort of developmental education service (Parks, 2001). Developmental and remedial educational coursework has both positive and negative implications for both the student who is in need of this coursework and the institution providing it. For students, developmental and remedial 
courses provide the opportunity to catch up to their peers and improve one's chances of college persistence and attainment (Martorell \& McFarlin, 2007). However, developmental and remedial courses increase the number of requirements for students and can extend the time to earn a degree and increase the costs to those students, which in turn might impact their persistence to graduation (Levin \& Calcagno, 2008). Upon accepting students into an institution of higher education, a college or university agrees to meet students' needs for academic success and eventual graduation. However, underprepared students pose a difficult financial problem for institutions of higher education. Breneman (1998) estimated the cost of remedial education to American institutions of higher education to be 1.05 billion dollars annually. It is debated whether or not those costs are justified in terms of economic outcomes and societal benefits associated with a college educated workforce. The results of this study may provide both scholars and practitioners with a clearer understanding of how effective the developmental programs of West Virginia public four-year institutions are for underprepared students. Education policy-makers can also use the findings and recommendations from this study to determine if such programs are successful in increasing the chances of degree completion for underprepared students.

\section{Definition of Terms}

1. A Nation at Risk Report: The Imperative for Educational Reform (1983): During President Ronald Reagan's administration the National Commission on Excellence in Education assessed the effectiveness of the United States secondary and primary educational systems in place and called for school reform.

2. A Test of Leadership: Charting the Future of Higher Education (2006): During President George W. Bush's administration, Education Secretary Margaret Spellings formed a 
Commission to assess the future of higher education and found that the United States higher education system needs to improve and be more accessible, more affordable, and more accountable.

3. ACT: American College Testing (ACT) is the assessment program that measures educational development and readiness to pursue college-level coursework in English, mathematics, natural science, and social studies. Student performance on the tests does not reflect innate ability and is influenced by a student's educational preparedness (NCES, 2009).

4. Coarsened Exact Matching (CEM): is a matching method that is within the category of quasi-experimental techniques and which creates a control and treatment group whose unobserved characteristics are not systematically related to the outcome of interest, thereby approximating a randomized controlled trial (Iacus, King, \& Porro, 2009).

5. Developmental Education: "broad range of courses and services organized and delivered in an effort to help retain students and ensure the successful completion of their postsecondary education goals" (Boylan \& Bonham, 2007, p. 2).

6. National Center for Education Statistics (NCES): part of the United States Department of Education and the primary federal entity for collecting and analyzing data related to education.

7. PROMISE Scholarship: (Providing Real Opportunities for Maximizing In-State Student Excellence) Scholarship Program that offered a full tuition scholarship to an in-state college or university or an equivalent dollar scholarship to an in-state private college to West Virginia high school graduates who had a 3.0 or higher grade point average and a composite ACT score of at least 21 or and combined SAT score of at least 1000. 
8. Remedial Education: instruction for a student lacking those reading, writing, or math skills necessary to perform college-level work at the level required by the attended institution (NCES, 2009).

9. SAT: formerly the Scholastic Aptitude Test and Scholastic Achievement Test, an examination administered by the Educational Testing Service and used to predict the facility with which an individual will progress in learning college-level academic subjects (NCES, 2009).

10. Underprepared Students: College and University students who enter institutions of higher education and who are not ready to complete college-level work.

11. West Virginia Higher Education Policy Commission (WVHEPC): is responsible for developing, establishing, and overseeing the implementation of a public policy agenda for the state's four-year colleges and universities.

\section{Organization of the Report}

Chapter One contains an introduction of the topic, the problem statement, the purpose of the study, the research questions, and significance of the study. The remaining chapters are organized as follows: Chapter Two begins by summarizing the national and state assessments of developmental education. It continues with an overview of the most important research discussing underprepared students, the costs incurred due to developmental and remedial educational programs, and the effectiveness of these programs. Chapter Three describes the description of the sample, the instruments, data collection, analysis techniques, and the research design used in this study. This chapter also includes the limitations of the study. Chapter Four provides the findings of the analyses. Chapter Five provides a summary and conclusions of the study as well as recommendations for practice and future research. 


\section{Chapter Two:}

\section{Review of the Literature}

The purpose of this literature review is to examine the body of research on developmental and remedial education. This chapter begins with the national and state assessments of the educational systems. It continues by providing an overview of the research discussing underprepared students and the costs incurred due to developmental and remedial educational programs. Next the effectiveness of the developmental and remedial educational programs is discussed as well as the assessments of three state remediation programs. This chapter concludes by discussing the minimum standards required of students entering West Virginia's public institutions of higher education as detailed by the West Virginia Higher Education Policy Commission.

\section{National and State Assessments of Education}

The status of the primary, secondary, and the higher educational systems in America has been a topic of concern for the past three decades. The effectiveness of each of these educational systems has been questioned and assessed by the United States of America's Department of Education in several studies (NCEE, 1983; Spellings, 2006). Although the educational systems in America are thought to be one of the premier educational systems in the world, these assessments called for actions to be taken to assure the future effectiveness of the United States primary and secondary educational systems.

During President Ronald Reagan's administration in 1983, the National Commission on Excellence in Education, under the direction of Terrell Bell, produced A Nation at Risk Report: The Imperative for Educational Reform (1983) that severely criticized the United States educational system. The report discussed the inadequate state of the current primary and 
secondary educational systems and called for reforms. The report detailed, among other things, the need for greater federal support of the American's primary and secondary educational systems due to the status of these systems. It stated that "The educational foundations of our society are presently being eroded by a rising tide of mediocrity that threatens our very future as a Nation and a people" (NCEE, 1983, p. 9).

A Nation at Risk Report (1983) brought attention to the assessment of effectiveness of primary and secondary educational systems. The report suggested that American students need a more rigorous curriculum and that the students and educators need to be held accountable for the outcomes of our educational system. Focus was placed on outcomes of education in relation to standards of achievement, with hope that this would improve student curriculum and accountability of the educational programs (Fraser, 2001). The educational goals in the report included higher graduation requirements in areas of English, mathematics, science, social studies, and computer science; higher standards and expectations for students and educators; extensions to the school day and year; and improved leadership and administrators to implement these reforms. Importance was placed on the intellectual, moral, and spiritual strengths of the students as areas that needed to be developed if students were to become contributors to society (NCEE, 1983).

A Nation at Risk Report (1983) asserted that the critical question for higher education was how to achieve educational quality without sacrificing access. It stated that, "The twin goals of equity and high-quality schooling have profound and practical meaning for our economy and society, and we cannot permit one to yield to the other in principle or in practice" (NCEE, 1983, p. 14). The report discussed the emergence of an internationally competitive market that placed a premium on highly skilled workers. The conclusion was that: 
The people of the United States need to know that individuals in our society who do not possess levels of skill, literacy, and training essential to this new era will be effectively disenfranchised, not simply from the material rewards that accompany competent performance, but also from the chance to participate fully in our national life. (NCEE, 1983, p. 4)

The main critics of $A$ Nation at Risk Report (1983) were educators. Although some educators felt that the report was justified and that changes were necessary to improve the school systems, other educators held a contrary point of view about the report. Berliner and Biddle (1995), in response to the report, began researching the topic themselves and published The Manufactured Crisis, which defended educators and expressed how they believed the federal government overstated and misrepresented the findings to create a crisis. Most critics of the report agreed that "more testing, a return to basic curriculum, traditional classroom instruction, and improved discipline were simplistic solutions for complex educational issues" (Urban \& Wagoner, 2004, p. 358). Both the non-critics and critics alike agreed there was a problem with the United States primary and secondary educational systems; however, the critics believed that problem was related to ethnicity, demographic, and economic shifts (Urban \& Wagoner, 2004). Students who leave primary and secondary education systems underprepared continue to be a major concern for higher education institutions.

George W. Bush, during his presidency, expressed the need for assessment of higher education institutions. As a result, Education Secretary Margaret Spellings formed a Commission to assess the future of higher education. A Test of Leadership: Charting the Future of Higher Education, the Commission's 2006 report, found that the higher education system in the United States of America needed improvement. The report recommended that actions be 
taken to make higher education more accessible, more affordable, and more accountable. In addition, the report reinforced the need for higher education leaders to do a better job of identifying, collecting, and disseminating information about tangible educational outcomes and demonstrable benefits of investment in the nation's colleges and universities. The report called for all Americans to join in the commitment to improve the higher education system so that the United States could maintain and assure a world-class higher education system.

The Spellings Commission (2006) reported that "We found that access to American higher education is unduly limited by the complex interplay of inadequate preparation, lack of information about college opportunities, and persistent financial barriers" (p. 1). Substandard high school preparation for college course work is exacerbated by the lack of cooperation between high schools and colleges. This lack of communication develops an "expectations gap" between what colleges require and what high schools produce. As evidence the commission reported that "According to the National Assessment of Educational Progress (NAEP), only 17 percent of seniors are considered proficient in mathematics, and just 36 percent are proficient in reading" (p. 1). Furthermore it stated that while high school graduates are attending colleges and universities at a higher rate, the rate at which college students have graduated has stayed the same. This is related to the fact that the shortcomings of high schools in preparing students for colleges and universities leads to an increased needs for students to take remedial education classes. "Remediation has become far too common an experience for American postsecondary students. Some 40 percent of all college students end up taking at least one remedial course at an estimated cost to the taxpayers of $\$ 1$ billion” (Spellings Commission, 2006, p. 8).

This report found that American high school students were not as prepared for college level coursework as those students from other countries (Spellings Commission, 2006). Other 
countries were rapidly improving their higher education systems while the United States education system remained inadequate. Graduation rates were decreasing and employers were reporting many of the new graduates they hired were not prepared to work because they lacked critical thinking, writing, and problem solving skills. The report stated that the United States higher education system was not prepared to meet the needs of transfer students or nontraditional students due to the lack of orientation programs and because most institutions have not expanded to accommodate the increased number of students. The overall findings of the report were that the American higher education system was not as effective as it could be and recommended that actions be taken to make it more accessible, more affordable, more accountable, and improve the overall quality of the education students received.

In 2001, The West Virginia Association for Developmental Education issued a report discussing the state of developmental education in West Virginia. This report focused on the extent to which West Virginia high school students were requiring developmental/remedial education services when attending college. Parks (2001) reported "According to the West Virginia Higher Education Report Card 2000, approximately one-half of all college freshmen in our state require some sort of developmental education service" (p. 64). Parks offered three main reasons, other than the socio-economic reasons, for developmental education's presence in higher education and the failure of students to meet West Virginia's minimum state requirements for entrance into college level courses in math and English.

The first issue plaguing West Virginia higher education institutions is the lack of state standards that require high school seniors to demonstrate their readiness for entry into introductory college courses (Parks, 2001). The high school graduation requirements do not always coincide with the expectations for entry into institutions of higher education. The second 
issue is that West Virginia higher education institutions are seeing increased numbers of nontraditional students due to previously unskilled jobs now requiring a more educated workforce (Park, 2001). To meet the job demands, workers are attending colleges and universities for the first time, thus requiring developmental education programs to reacquaint themselves with basic educational competencies. The third issue impacting West Virginia institutions of higher education is the increase in non-native students enrolling in developmental skills courses. As part of an orientation process foreign students are placed in developmental programs as a way to better prepare them for success in their educational pursuits.

Parks (2001) also discussed some areas of concern with West Virginia's developmental education programs. The first of these was that colleges and universities are using inappropriate placement mechanisms for incoming students. "The State College System of West Virginia mandates include minimum ACT and SAT scores in math and English" (Parks, 2001, p. 8). One concern is that although standardized tests were not created to function as placement tests, their use provides a cost-efficient and convenient placement instrument for institutions of higher education. Another area of concern is that developmental programs are being taught by parttime employees and not by full-time faculty and staff. Parks (2001) stated that"...only 3.3 percent of full-time staff and 5.9 percent of full-time faculty in American higher education work with developmental students" (p. 9). Due to the popularity of on-line courses, administrators have started to make developmental courses available as web courses. Parks (2001) believes this causes concern due to the lack of human interaction and the potential for student drop-out and withdrawal.

Parks (2001) concluded with a discussion of the increased number of high school students enrolling in developmental skills courses prior to entering college. While still enrolled 
as high school students some students are taking college courses in an attempt to earn college credit prior to entering college full-time. In many cases they are not ready for college level course work and are required to take some form of developmental or remedial coursework. These students are not exhausting all of the resources available to them because these same courses are offered in their high schools. Although there are many issues surrounding the developmental education programs, Park (2001) still believed that developmental education is a vital and necessary service provided by West Virginia institutions of higher education to meet these students' needs.

According to the West Virginia Higher Education Report Card, in the fall of 2002, 25 percent of recent high school graduates entering public four-year institutions required some type of developmental courses (West Virginia Higher Education Policy Commission, 2003). While 15 percent enrolled in an English-related developmental course, a full 30 percent of students required remediation in math. The report also notes that non-traditional students, defined as those aged 25 and over, were more likely to require these courses with 27 percent requiring English-related courses, 44 percent requiring math, and 51 percent requiring any developmental courses.

The Editorial Projects in Education Research Center (2010) compared West Virginia's primary and secondary students with students in the other 50 states and the District of Columbia. The study focused on different academic areas of West Virginia's state education system and compared them to the national average. The areas that were examined included the Math Progress Index, the Chance-of-Success Index, the Standards, Assessments, and Accountability Index, the Teaching Profession Index, the School Finance Index, the Transitions and Alignment 
Index, and the K-12 Achievement Index. These indexes were used to grade the effectiveness of West Virginia's public schools.

Areas where West Virginia education received grades higher than the national average included the Standards, Assessments, and Accountability Index, the Teaching Profession Index, the School Finance Index, and the Transition and Alignment Index (Editorial Projects in Education Research Center, 2010). The Standards, Assessment, and Accountability Index examined academic standards, assessment measures to evaluate student performance, and school accountability for reporting student records. In this area West Virginia received an A grade compared to the national average of a B grade. The Teaching Profession Index evaluated West Virginia on its efforts to improve teaching and accountability, giving it a grade of B- compared to a national average of a C. The School Finance Index examined if West Virginia allocated its fiscal recourses responsibly based on the wealth of the school districts, the percentage spent on each student equally, the percentage spent per district, and the amounts spent on education as a percent of the state's taxable resources. West Virginia received a $\mathrm{C}+$, where as the national average was a C. The Transition and Alignment Index examined how the state connected the K12 program with early learning opportunities, higher education, and preparation for the workforce. Here West Virginia fared well and received an A, whereas the national average was a C.

According to the study by the Editorial Projects in Education Research Center (2010), areas where West Virginia did not receive grades higher than the national average included the Chance-for-Success Index, the Math Progress Index, and the K-12 Achievement Index. The Chance-for-Success Index examined thirteen indicators that span an individual's life to identify what part education plays in their success. West Virginia received a $\mathrm{C}$ - and the national average 
was a C + . The Math Progress Index examined student's mathematical performance in primary and secondary school improvement from 2003-2009, and the opportunities available in the field of mathematics and received a failing grade. The national average for The Math Progress index was a D. In the K-12 Achievement Index researchers examined achievement levels in math and reading, achievement gains in math and reading, the poverty gap, graduation rates, achieving excellence or above average scoring in math, and Advanced Placement scores. Again West Virginia received a failing grade and finished 48 out of 50 among states.

This study showed that the West Virginia's educational system ranked below the national average in most of the academic categories and finished in the bottom half for student graduation. The overall assessment based on the K-12 Achievement Index score placed West Virginia 49 out of 50 states with only Mississippi finishing lower. The District of Colombia also finished lower then West Virginia in the K-12 Achievement Index. In an effort to accommodate these students, institutions must take the necessary steps to assure they can overcome the areas in which they lack the proper preparation to complete college level work.

\section{Underprepared Students}

Universities and colleges, from their conception, were designed as places where students came to find meaning in life, develop morally, and gain knowledge as an end in itself (Cohen, 1998). Colleges and universities work to design programs for students to assist them in identifying and developing suitable programs of study, providing enriching experiences, expanding their horizons, and offering opportunities to make students aware of their talents, skills, and options that they have to be successful. Although there are many influences that have had an impact on the landscape of American higher education institutions, one area that has been consistent is the need for developmental/remedial education. 
Both developmental education and remedial education refer to coursework for underprepared students. Although distinctions can be made between developmental education and remedial education, for the purposes of this study, these terms will be used interchangeably. Developmental/remedial educational courses differ at institutions of higher education (NCES, 1996). The three major areas of education that are most commonly described as developmental/remedial education include reading, writing, and mathematics.

Usually these courses are neither included in subsequent grade point average calculations nor are they counted toward fulfillment of certificate or degree requisites (NCES, 2003). The most intensive programs offered by developmental education programs are remedial courses. Remedial education is defined by the National Center for Educational Statistics' Digest of Educational Statistics as "Instruction for a student lacking those reading, writing, or math skills necessary to perform college-level work at the level required by the attended institution" (2009, p. Appendix B). According to Parsad and Lewis (2003), remedial education is defined as "courses in reading, writing, or mathematics for college-level students lacking those skills necessary to perform college-level work at the level required by the institution" (p.1) Remedial courses focus on educational competencies that are considered to be precollege content which students were expected to have mastered prior to enrolling,

According to Boylan and Bonham (2007), "Developmental education refers to a broad range of courses and services organized and delivered in an effort to help retain students and ensure the successful completion of their postsecondary education goals" (p. 2). Less intensive developmental education programs include student advising, workshops, learning laboratories, individualized instructions, and both group and individual tutoring (Boylan \& Bonham). Although the services encompassed by developmental/remedial education differ in their level of 
intensity, each plays an important role in student success. While there are many definitions that adequately describe developmental/remedial education, for the purposes of this study the following definition was formulated: developmental/remedial educational courses are instructional classes designed for students who are deficient in competencies necessary for successful college work.

Many studies address the issue of underprepared students at American institutions of higher education (Mulvey, 2008; Parks, 2001; Payne \& Lyman, 1996; Schmidt, 2006; Stephens, 2001; Tierney \& Garcia, 2008;). Numerous American high school graduates gain admission to postsecondary institutions only to find that they are not prepared for college-level work. Roueche and Roueche (1993) report that students today "are leaving high school no better prepared [for college] than they were in the mid-1960s. In fact, evidence indicates that despite higher grade point averages, these students' skills and competencies are at the lowest levels in American history" (p.246). Some of the responses by institutions of higher education to these underprepared students include setting higher admission standards so that those who are not ready for college-level work are not admitted; admitting students and providing them with remedial courses; or working with high schools to develop better developmental programs to prepare students for the rigors of college academics (Tierney \& Garcia, 2008). Underprepared students pose a set of challenges for institutions that opt to provide developmental/remedial coursework including increased numbers of faculty to teach these courses, and increased costs to both the student and the institution (Mulvey, 2008; Parks, 2001; Payne \& Lyman, 1996; Schmidt, 2006; Stephens, 2001; Tierney \& Garcia, 2008).

Far too many students arrive at institutions of higher education with weak academic skills and are unable to do college-level school work. Many of these students are under challenged, 
have poor study habits, and do not see value in their assignments and college courses. As cited in Mulvey (2008), Levin and Cureton (1998) discussed how students were arriving with less preparation than in previous years and that a Student Affairs Survey (1997) indicated that 73 percent of student affairs officials noted "an increase in the proportion of students requiring remedial or developmental education at two-year (81 percent) and four-year (64 percent) colleges" (p.128) As cited in Mulvey (2008), the Association of American Colleges and Universities (2004) stated that "Once in college, almost half of all students must take remedial coursework of some kind" (p. 2). Venezia, Callan, Finney, Kirst, and Usdan (2005) noted that "Nationally, 63 percent of students in two-year colleges and 40 percent of those in four-year institutions take some remedial education" (p. ix).

Venezia, Callan, Finney, Kirst, and Usdan (2005) described some of the issues that caused students to enter institutions of higher education underprepared. They described many of the issues of high school graduates who are not prepared for college. These issues included the following:

- the intensity and quality of high school courses,

- inequities in college preparation opportunities,

- high school achievement gaps,

- a confusing array of state and institutional exams within and between the education sectors,

- high postsecondary remediation rates,

- insufficient college persistence and completion,

- and postsecondary achievement gap. ( p. 2) 
Due to the high numbers of students who enter institutions of higher education underprepared for collegiate coursework, remediation in postsecondary curricula is a contentious issue (Mulvey, 2008). There is not full agreement on the effects of remedial education on graduation rates (Adelman, 1996; Tierney \& Garcia, 2008). Adelman (1996) found an inverse relationship between a student's need for remediation and completion of a degree. Students who started their education at a two-year institution, where many students require remediation, were less likely to obtain a bachelor's degree than those students who started at a four-year institution (Shaw, 1997; Tierney \& Garcia, 2008). As cited in Boyce's (2007) dissertation, "Students who matriculate with a strong academic preparation (in high school) are more likely to graduate than...those who have deficiencies in English and math" (Sauchuk, 2003, p. 99).

Remedial educational programs focus on three main areas of academics: reading, writing, and mathematics. Researchers have concluded that students who are deficient in reading are less likely to be successful academically. Referred to by Tierney and Garcia (2008), Attewell, Lavin, Domina, and Levey (2006) examined the National Longitudinal Study of 1988 data and found that:

Students who took remedial coursework in reading at a four-year college had between a 7 percent (logistic model) and 11 percent (propensity model) lower probability of completing a degree than otherwise identical students who did not enroll in remedial reading (p. 909).

Attewell and colleagues (2006) concluded that students who took remedial reading educational courses had lower graduation rates, citing factors such as the extra courses that need to be taken, the extra time that is required to take these courses, and the extra money that it costs to take these courses. Adelman (1996) found that students who are underprepared in the subject of English, 
which includes reading and writing, are at a vast disadvantage to complete college level work than those students who have mastery of basic language skills.

Students who enroll in developmental/remedial education programs face many issues to succeed academically. Geehan (2004), as cited in Boyce (2007), discussed in her dissertation the issues facing 31 upstate New York State community college students who were attending a noncredit developmental English course:

Despite determination to succeed academically and to establish meaningful careers and lives, many of the students were caught in a self-perpetuating cycle of low achievement, working against their own success...[additionally] the influence of friends was considerable, and their aspirations, or lack thereof, were reflective of the students' own. (Geehan, p.111-1v)

Such factors can influence the outcome of a student's academic endeavors and lead to failure.

Despite students' goals to obtain a degree while at college, many students are unprepared to succeed and to complete their college programs. Venezia, Callan, Finney, Kirst, and Usdan (2005) discussed how half of first-year students at community colleges do not continue on for a second year and that approximately one quarter of first-year students at four-year colleges do not stay for their second year. Withdrawal decisions are the result of complex issues specific to each student. Student withdrawal from institutions of higher education may be attributed to different factors at different times of the academic year and at different points in the progression to obtain a degree. Tinto, Goodsell, and Russo (1994) suggest that social and academic integration into college is a critical part of retention for students in their first year. They also argue that withdrawal in students' later years is based less on the level of integration and more on the quality of their educational experience. Economic factors and placement into 
developmental education courses have also influenced student withdrawal from institutions of higher education.

At some institutions students are required to take developmental/remedial education courses based on placement tests, ACT/SAT scores, and/or high school grade point averages (NCES, 2003). Due to placement in remedial coursework resulting from the standards set by these institutions the students lose their choice of course selection. This could be one factor in the lack of retention of students in developmental/remedial education. Aldridge and Rowley (2001) argue that the lack of course choice is one of the most significant predictors of withdrawal from an institution of higher education. Levin (1999) summarized a broad array of research and supported the argument that students who are required to take many remedial courses get discouraged and drop out. Roueche, Milliron, and Roueche (2003) describe the following characteristics that put students at risk of academic failure; first-generation status, poor selfimage, self defeatism, having unreachable goals, working 30 hours per week, average age 29, poverty, academically weak, and poor or low test scores or GED scores. (p. 7)

NCES has done several national studies on the size and extent of programs for underprepared students at American institutions of higher education. NCES's study in 1996 found that developmental/remedial courses in mathematics, writing, or reading were offered by 100 percent of all public two-year colleges, 81 percent of all public four-year colleges, and 63 percent of all private four-year colleges. According to a more recent study by the NCES (2003), 98 percent of community colleges, 80 percent of all public four-year colleges, and 59 percent of all private four-year colleges offered developmental courses.

The National Center for Educational Statistics (1996) found that 78 percent of higher education institutions with freshmen offered at least one developmental course and NCES (2003) 
found that in 2000, 76 percent of institutions of higher education that enrolled freshmen offered at least one remedial reading, writing, or mathematics course. NCES (1996) reported the percentage of freshmen enrolled in developmental courses had not increased appreciably from the preceding reports. In 1995, twenty-eight percent of college freshmen enrolled in at least one developmental class at institutions of higher education, and the percentage remained consistent in the following years. NCES (2003) reported that "Between 1995 and 2000, no differences were detected in the proportion of entering freshmen who enrolled in at least one remedial reading, writing, or mathematics course" (p. iv). In 1995, 16 percent of incoming college freshmen needed development in writing, 44 percent needed development in math, and 34 percent needed reading developmental classes (NCES, 1996). In 2000, "No differences were detected in the proportion of freshmen who were enrolled in remedial reading or mathematics, although the proportion of freshmen enrolled in remedial writing declined from 16 to 14 percent" (NCES, 2003, p.18).

Regarding length of time students are involved in developmental education, NCES (1996) reported that 67 percent of institutions had students who required less than one year of remediation. Twenty-eight percent of the students required an average of one year of remediation, while only five percent of the students required more than one year of remediation. By 2003, 60 percent of the institutions studied had students who required less than one year of remediation, thirty-five percent of students required an average of one year of remediation, and five percent of students required more than one year of remediation. Data collected between 1995 and 2000 on the reported time spent in remediation suggests an increase in the average length of overall time that students spent in remedial education courses (NCES, 2003). 
The National Center for Educational Statistics $(1996,2003)$ also looked at institutions of higher education that differ in their selection of incoming students for remedial education. Some of the ways that institutions screened students for remedial education courses included placement tests for all incoming students, placement tests for those students who entered the institution with low ACT/SAT scores or a low high school grade point average. Students who enter college with low ACT/SAT scores and or low high school grade point averages, in some instances, are required to take remedial education classes. In some cases where students were experiencing regular course difficulties they self selected to take remedial courses or their professors' recommended remedial course work (NCES, 2003).

NCES (1996) reported that in 1995, 58 to 64 percent of higher education institutions used placement tests to determine whether or not incoming freshmen needed remediation regardless of ACT/SAT scores or high school grade point average. The second most used practice, in 22 to 25 percent of institutions, required entering students to take placement tests because they had low ACT/SAT scores and or low high school grade point averages (NCES, 1996). The third most implemented approach, at eight to ten percent of institutions, did not employ placement tests, but required or encouraged entering students with low ACT/SAT scores and or low high school grade point averages to enroll in remedial courses (NCES, 1996). NCES (1996) reported that six to nine percent of institutions of higher education used other means of selecting entering students for remedial coursework.

NCES (2003) reported that in 2000, 57 to 61 percent of higher education institutions used placement tests to determine whether or not incoming freshmen needed remediation regardless of ACT/SAT scores or high school grade point average. The second most used practice, in 25 to 29 percent of institutions, required entering students to take placement tests because they had low 
ACT/SAT scores and or low high school grade point averages (NCES, 2003). The third most implemented approach, at 10 to 12 percent of institutions, did not employ placement tests, but required or encouraged entering students who met various criteria, low ACT/SAT scores and or low high school grade point averages, to enroll in remedial courses (NCES, 2003). NCES (2003) reported that two to four percent of institutions of higher education used other means of selecting students for remedial coursework. NCES (2003 \& 1996) found that colleges and universities have stayed relatively unchanged in determining how and when students are placed into developmental/remedial educational coursework. (see also Table 1)

\section{Table 1}

Institutions' Selection Method for Remedial Education. (NCES, 1996 \& 2003)

\begin{tabular}{lcc}
\hline Method Used & NCES 1996 & NCES 2003 \\
\hline \hline $\begin{array}{l}\text { Required Placement Tests for } \\
\text { all incoming Freshmen }\end{array}$ & $58 \%$ to $64 \%$ & $57 \%$ to $61 \%$ \\
$\begin{array}{l}\text { Required Placement Tests due } \\
\text { to ACT/SAT scores or H.S. }\end{array}$ & $22 \%$ to $25 \%$ & $25 \%$ to $29 \%$ \\
$\begin{array}{l}\text { GPA } \\
\text { Required due to ACT/SAT }\end{array}$ & $8 \%$ to $10 \%$ & $10 \%$ to $12 \%$ \\
$\begin{array}{l}\text { scores and or H.S. GPA } \\
\text { Other }\end{array}$ & $6 \%$ to $9 \%$ & $2 \%$ to $4 \%$ \\
\hline
\end{tabular}

The approach that an institution used to determine entering students placement in remedial coursework differed by institutional type. (see also Table 2) The most commonly used approach was to require that all incoming students take placement tests. Two-year institutions used this approach, more frequently than did both public four-year and private four-year institutions. NCES (1996) reported that in 1995, two-year institutions used this process for determining placement of a student in remediation for remedial reading 69 percent of the time, 68 percent for remedial writing, and 69 percent for remedial mathematics. NCES (1996) reported that public and private four-year institutions used this process 37 percent (public) and 
46 percent (private) for remedial reading, 49 percent (public) and 48 percent (private) for remedial writing, and 53 percent (public) and 56 percent (private) in mathematics. NCES (2003) reported that two-year institutions used this process 63 percent for remedial reading, 86 percent for remedial writing, and 87 percent for remedial mathematics. NCES (2003) reported that public and private four-year institutions used this process 44 percent (public) and 49 percent (private) for remedial reading, 54 percent (public) and 50 percent (private) for remedial writing, and 55 percent (public) and 54 percent (private) in mathematics. Snyder (2001) explained that one reason for this difference between two-year institutions and four year public and private institutions is that four-year institutions rely more heavily on ACT/SAT scores and grade point average to determine the remedial needs of the incoming student.

Table 2

Percent of Institutions Using Placement Tests for All Students for Developmental Placement by Institutional Type. (NCES, 1996 \& 2003)

\begin{tabular}{|c|c|c|c|c|c|c|}
\hline \multirow[b]{2}{*}{ Inst. Type } & \multicolumn{3}{|c|}{ NCES 1996} & \multicolumn{3}{|c|}{ NCES 2003} \\
\hline & Reading & Writing & Math & Reading & Writing & Math \\
\hline 2-Year & $69 \%$ & $68 \%$ & $69 \%$ & $63 \%$ & $86 \%$ & $87 \%$ \\
\hline $\begin{array}{l}\text { 4-Year } \\
\text { (Private) }\end{array}$ & $46 \%$ & $48 \%$ & $56 \%$ & $49 \%$ & $50 \%$ & $54 \%$ \\
\hline $\begin{array}{l}\text { 4-Year } \\
\text { (Public) }\end{array}$ & $37 \%$ & $49 \%$ & $53 \%$ & $44 \%$ & $54 \%$ & $55 \%$ \\
\hline
\end{tabular}

\section{Costs of Developmental/Remedial Education}

Concerns about the cost of developmental/remedial education courses have become an issue of debate at institutions of higher education. According to Breneman and Haarlow (1998) as referenced in Kozeracki (2000), developmental education cost the nation's public colleges and universities about one billion dollars annually. Schmidt (2006) stated that, "Higher-education 
institutions are already spending billions of dollars on remedial education for students who arrive on campuses unprepared for college-level work" (p. 1). According to Saxon and Boylan (2001), "Critics argue that remedial education costs taxpayers twice, teaching academic skills in college that students should have acquired in high school" (p. 2).

Saxon and Boylan (2001) discussed three different national studies that examined the costs of developmental/remedial education courses to institutions of higher education. The first two studies discussed included Breneman (1998) and Brenman and Haarlow (1998) which both estimated the costs of remedial education to American institutions of higher education to be one billion dollars annually. In the third study that Saxon and Boylan examined, Abraham (1998) discussed different methods of calculating what the cost of remedial education was to institutions of higher education. Abraham (1998) used three different methods of calculating the cost that took into account nationally reported estimates of the total educational budget, the reported percentage of freshman students in remedial education courses, and the estimated remedial course load of the students. Abraham found that the estimates of the total cost of remediation were well below one billion dollars and ranged from $\$ 260,500,000$ to $\$ 580,700,000$. Saxon and Boylan (2001) do note that Breneman (1998), Breneman and Haarlow (1998), and Abraham (1998) are all supporters of the spending required for remedial education.

Not surprisingly, many states are concerned about the costs incurred by offering developmental/remedial educational programs. Bettinger and Long (2005) conducted a study that examined Ohio’s remedial education programs. The Ohio Board of Regents (2001), as cited in Bettinger and Long (2005), stated that, “In Ohio, public colleges spent approximately \$15 million teaching 260,000 credit hours of high school-level courses to freshmen in 2000; another \$8.4 million was spent on older students" (p. 1). 
Advocates of developmental education offer rationales that are based on economic outcomes, societal benefits, and issues of fairness. Kozeracki (2002) cited a study by the Institute for Higher Education Policy (1998) that indicated that developmental education was less costly than sending an uneducated group into society. It was determined that the lack of developmental education would lead to unemployment, low-wage jobs, welfare participation, and incarceration, whereas developmental education would lead to increased numbers of students who remained in college, earned a degree, and contribute to society. Calcagno and Long (2008) contend that one year of college, even without degree completion, has an educational return to the student.

Still, there are many concerns related to the costs of developmental/remedial education programs at institutions of higher education. Opponents argue that any benefits of remediation are outweighed by the high costs of remedial/developmental education programs (Martorell \& McFarlin, 2007). Calcagno and Long (2008) question whether the benefits of remediation courses are worth the costs of providing them. They question if the $\$ 118.3$ million dollars annually incurred by institutions for remediation programs and the one to two billion dollars incurred annually for the states for remediation are justified. They also question if the cost to the student, on average an additional $\$ 504$ for remedial education, are justified if there is no change in a student's degree completion rate. Furthermore, not all agree that financial aid should be made available to students enrolled in developmental/remedial education courses (Saxon \& Boylan, 2001).

Cost concerns have led some institutions of higher education to consider the reduction or elimination of developmental/remedial courses they offer (Kozeracki, 2002; Martorell \& McFarlin, 2007). Due to the costs incurred by these education programs and the large number of 
students that are required to take developmental/remedial education, a question arises as to where remediation should take place, either at two-year institutions exclusively or at both two-year and four year-institutions. Jenkins and Boswell (2002) stated that ten states disallow or discourage public four-year institutions from offering remedial education and that many states restrict remediation to only two-year institutions.

Advocates who encourage the restriction of developmental/remedial education courses to two-year institutions of higher education believe that it would be less costly than providing these courses at four-year institutions. On the other hand, Levin \& Calcagno (2008) cite Astin (2000) in opposing this two-year institution restriction on developmental/remedial education. The researcher contends that two-year institutions are not as adequately equipped or funded, to deal with underprepared students as are four-year institutions of higher education.

Concerns about the cost of developmental/remedial education courses continue to be a highly debated issue at institutions of higher education. Advocates of developmental/remedial education courses contend that based on economic outcomes, societal benefits, and issues of fairness these courses are necessary (Abraham, 1998; Breneman, 1998; Breneman \& Haarlow, 1998). Conversely, opponents of developmental/remedial education courses believe the costs of developmental/remedial education to both the student and the institution are too high and that the benefits do not outweigh the costs (Kozeracki, 2002; Levin \& Calcagno, 2008; Martorell \& McFarlin, 2007;). Although researchers on each side of this debate agree that students are not prepared for the rigors of college, they disagree on how this issue should be corrected.

\section{Effectiveness of Developmental/Remedial Education Programs}

The effectiveness of developmental/remedial education courses has been one of the most controversial issues in higher education in recent times (Adelman, 1996; Grubb, 2001; Levin \& 
Calcagno, 2008; Levin \& Koski, 1998; McCabe, 2000; McCabe, 2003; Payne \& Lyman, 1996; Tierney \& Garcia, 2008). In addition, researchers question the reliability of the studies examining the effectiveness of developmental/remedial education programs. Schmidt (2006) stated that:

Research into the effectiveness of developmental programs for college students has been sporadic, typically underfunded, and often inconclusive: Many factors have hindered research into the effects of developmental classes, study skills courses, tutorials, and counseling programs on the performance of underprepared college students. (p. 5) Grubb (2001) discussed how, "Relatively few evaluations of remedial programs have been conducted, and many existing evaluations are useless because, failing to recognize what the program does, they provide little information about what should be changed to make it more effective" ( p. 1). Some researchers have found evidence in favor of the effectiveness of remedial coursework (Bettinger \& Long, 2005; Levin and Koski, 1998; McCabe, 2000; McCabe, 2003), and others have found the opposite (Adelman, 1996; Grubb, 2001).

Developmental/remedial educational services however, have allowed students of varying abilities and backgrounds to continue at institutions of higher education (Bettinger \& Long, 2005; Boylan, Bonham, \& White, 1999; Tierney \& Garcia, 2008). Supporters of remediation believe that these programs help poorly-prepared students succeed in college by providing a chance to catch up to their peers and find positive effects of remediation on college persistence and attainment (Martorell \& McFarlin, 2007). McCabe (2000) discussed how remediation has proven to be effective at improving the chances of collegiate success for underprepared students. In order to improve the performance of students in developmental/remedial education courses, 
researchers have focused on the components of the developmental/remedial programs to evaluate the effectiveness of these programs.

Nevertheless, some researchers found that effective developmental/remedial programs shared certain aspects and characteristics. Levin and Koski (1998), as cited in Levin and Calcagno (2007), based on previous research on remedial education in higher education institutions found the following aspects to be central for designing successful interventions for underprepared students in higher education:

- Motivation: building on the interests and goals of the students and providing institutional credit toward degrees or certificates.

- Substance: building skills within a substantive or real-world context as opposed to a more abstract approach.

- Inquiry: developing students' inquiry and research skills to help them learn about other subjects and areas about which they might be curious.

- Independence: encouraging students to do independent meandering within the course structure to develop their own ideas, applications, and understandings.

- Multiple Approaches: using collaboration and teamwork, technology, tutoring, and independent investigation as suited to student needs.

- High Standards: setting high standards and expectations that all students will meet if they make adequate efforts and are given appropriate resources to support their learning.

- Problem Solving: Viewing learning less as an encyclopedic endeavor and more as a way of determining what needs to be learned and how, and then implementing "the how." 
- Connectiveness: emphasizing the links among different subjects and experiences and how they can contribute to learning rather than seeing each subject and learning experience as isolated and independent.

- Supportive Context: recognizing that to a large degree learning is a social activity that thrives on healthy social interaction, encouragement, and support. (pp. 5-6) McCabe (2000) conducted a national study of community college remedial education programs to discover factors that lead to student success, retention, and eventually degree completion. Those factors include:

- Implementation of mandatory assessment and placement,

- Establishment of clearly specified goals and objectives for developmental programs and courses,

- Use of mastery learning techniques in remedial courses,

- Provisions of a high degree of structure in remedial courses,

- Use of a variety of approaches and methods in remedial instruction,

- Application of sound cognitive theory in the design and delivery of remedial courses,

- Provision of a centralized or highly coordinated remedial program,

- Use of a formative evaluation to guide program development and improvements,

- Establishment of a strong philosophy of learning to develop program goals and objectives and to deliver program services,

- Provision of a counseling component integrated into the structure of remedial education,

- Provision of tutoring performed by well-trained tutors,

- Integration of classroom and laboratory activities,

- Establishment of an institution wide commitment to remediation, 
- Assurance of consistency between exit standards for remedial courses and entry standards for regular curriculum,

- Use of learning communities in remedial instruction,

- Use of supplemental instruction, particularly video-based,

- Provision of courses or workshops on strategic thinking,

- Provision of staff training and professional development for those who work with underprepared students,

- Provision of ongoing student orientation courses,

- And integration of critical thinking into the remedial curriculum. (p.45)

McCabe (2003) again revisited the concept of effectiveness of remedial education programs and provided a guide for effective developmental programs. McCabe's (2003) 16 Steps For An Effective Developmental Program include:

1. Avoid the negative connotation of remedial, choosing a more positive term like developmental or preparatory to describe a program for underprepared students.

2. Adopt a centralized approach, or at least carefully coordinate the various units involved in program delivery.

3. Adopt goals for the total program effort, even if there is not a single remedial unit.

4. Provide professional development for all faculty and staff who work with underprepared students.

5. Recognize that at-risk students need structure in courses and support services.

6. Recognize the importance of student orientation for new enrollees.

7. Incorporate counseling, study skills, and learning communities or cohort groups in the program. 
8. Integrate the work of tutors and mentors with carefully selected faculty members.

9. Address the issues of assessment, placement, late registration, and simultaneous enrollment in college-level courses, including mandatory assessment and mandatory placement.

10. Establish consistency between exit standards for remedial courses and entry standards for college-level courses.

11. Provide supplemental learning opportunities, particularly for skill practice.

12. Find the appropriate use of technology and media to support student learning.

13. Consider a case management approach for the least prepared students.

14. Embrace a variety of approaches and methods in program delivery.

15. Commit to program evaluation and the dissemination of results.

16. Expand and enhance pre-enrollment activity with the public schools. (p.25)

As previously discussed, researchers Levin and Koski (1998) and McCabe (2000 \& 2003) take the stance that developmental/remedial education is effective when implementing the above elements into their program's design. Other researchers are as not as confident in the effectiveness of developmental education programs and find little consistent evidence that remediation has positive effects for student success. Tierney and Garcia (2008) questioned the effectiveness of developmental/remedial education programs and stated, "Scholars also have questioned whether such courses are effective in helping students to graduate from college" (p. 1). Levin and Calcagno (2008) stated that, "There is in fact little definitive evidence on the effectiveness of remedial courses and practices on persistence to graduation, quality of performance in subsequent courses, grade point average, and so on in the relevant literature" (p. 
4). Adelman (1996) found an inverse relationship between a student's need for remediation and completion of a degree.

The ongoing debate on the effectiveness of developmental/remedial education continues to be an issue at institutions of higher education. Bettinger and Long (2005) pointed out that increasing the number of requirements for students could extend the time to earn a degree and may negatively impact student outcomes such as persistence and major choice. They further stated that some critics believe that the incentive for students to adequately prepare while in high school diminishes due to the availability of developmental education course at the collegiate level. Grubb (2001) stated:

With evaluation of remedial education still in its infancy, no one knows much about what works and what does not. The little evidence indicates that completion rate in remedial courses are low, that the amounts of remediation to important outcomes like persistence in and completion of college programs, and the learning communities are probably more effective than stand-alone classes" (p. 3).

Martorell and McFarlin (2007) discussed the considerable uncertainty surrounding the effectiveness of remediation and argued that the impact of remediation is difficult to assess. Brothen and Wambach (2004) believe that:

If remedial courses are to remain an important part of developmental education, researchers need to determine if they truly prepare students for future college work and how the courses fit into the full range of services for developmental students. Evaluating students on traditional outcome measures such as retention, grades in the next course, and grades in the "regular" curriculum may be the best way to answer this question. (p. 17) 
Bettinger and Long (2005) conducted a study using data from the Ohio Board of Regents (OBR), for 28,000 full-time, 18-20 year old freshmen at Ohio public colleges over a five-year time frame from 1998 to 2003 , to investigate the impact of remediation on college performance and persistence. Bettinger and Long (2005) reported that remedial education had a positive impact on the college outcomes of underprepared students. They found major differences from the results reported by the Ohio Board of Regents and the results they collected using the instrumental variables (IV) strategy. The Ohio Board of Regents, as cited in Bettinger and Long (2005), found that students in math remediation were 13.7 percent more likely to drop out and 10.8 percent less likely to graduate within five years than students not in remediation. Bettinger and Long however found that students in remedial math courses are nearly 10 percent less likely to drop out than students who share similar characteristics academically. In English remediation, students were 9.7 percent less likely to drop out and 9.3 percent more likely to graduate within five years than students who share similar characteristics academically. They found no difference in the effect of remediation on students by subject of interest; however, taking remediation in certain subjects can have discouragement effects on students' major choice. Bettinger and Long also found that underprepared students without remediation courses were more likely to drop out of college and less likely to complete their degrees.

In their study, Bettinger and Long (2005) found that students with similar test scores and backgrounds at Ohio institutions of higher education who were placed in remediation were more likely to persist in college compared to those students with similar test scores and backgrounds at Ohio institutions of higher education who were not required to take the courses. Thus they concluded that remediation in Ohio institutions of higher education was having a positive impact on the college outcomes of under-prepared students. 
An Attewell, Lavin, Domina, and Levey (2006) study is a comprehensive analysis of the effects of remedial education at the national level for the 1992 cohort of high school graduates that had different conclusions. In the study propensity score matching is used on NELS: 88 data to assess whether taking any or many remedial courses and successfully completing remedial courses affect student outcomes. They found that both taking any and many (three or more) remedial courses lowered bachelor degree attainment and also increased time to degree. However, if a student successfully completed all remedial coursework in an area, it increased the likelihood of completing a two-year degree over similar students who did not take remedial courses. Four-year completion, however, was not affected by remedial course completion. Nevertheless, Attewell et al. point to the surprisingly large numbers of remedial students who complete both two-year and four-year degrees despite inadequate academic preparation.

Martorell and McFarlin (2007) examined the impact of remediation on a sample of 255,878 two-year college students and 197,592 four-year college students who entered Texas institutions between the 1991-1992 and 1999-2000 school years as first-time students. In Texas, all students who are pursuing an academic degree are tested to determine if they need remediation. To determine if a student is college ready, they are required to take the Texas Academic Skills Program (TASP) test and or the ACT/SAT (Martorell \& McFarlin, 2007). The results of these scores determine whether or not students are placed in remedial classes. They examined those students whose test scores were just above the cutoff and not required to take remedial classes in math and English and those students who were just below the cutoff who were required to take remedial math and English classes.

Martorell and McFarlin (2007) found little support for the effectiveness of remediation noting that remediation did not improve the outcomes of Texas students at both two-year and 
four-year institutions. The one exception was that students assigned to math remediation received better grades in their first math class than those students who did not receive any remediation in math. They argue that, “... the marginal Texas student does not benefit from mandatory remediation despite the substantial financial cost of the program" and that "...we find no indication that remediated students have better labor market outcomes than comparable nonremediated students" (Martorell \& McFarlin, 2007, pp. 23-24).

Calcagno and Long (2008) conducted a study were they evaluated math and English remediation at institutions of higher education in Florida. Their study examined a sample of 100,000 first-time Florida community college students from fall 1997 to fall 2000 who were seeking at least an Associate of Arts degree. In this study Calcagno and Long (2008) looked at students who were academically similar in their test scores, or those whose test scores were just above the cutoff requiring them not to have to take remedial classes in math and English and those students who were just below the cutoff requiring them to take remedial math and English classes. Their findings suggested the remedial classes, in some instances, have an impact, and in other instances, do not have an impact on student success. For example, those students who required math remediation were more likely to persist to their second year of education than those students who were not required to take remediation in math. Also, those students in both math and reading remediation earned more total number of credits over six years than those students who were not required to take remediation. While these findings suggested that remediation might promote early persistence in college, it may not translate to degree completion.

Based on their study, Calcagno and Long (2008) do not believe that remedial education is ineffective and harmful but instead believe that remediation has a place in higher education. 
These findings are not as optimistic as the conclusions drawn by Bettinger and Long (2005) who found positive effects of remediation on students in Ohio, but instead are more in accordance with the findings of Martorell and McFarlin (2007) which provided little support for the effectiveness of remediation at higher education institutions in Texas.

\section{West Virginia Higher Education Policy Commission Standards}

As previously mentioned, some states require students to take developmental/remedial education courses based on placement tests, ACT/SAT scores, and or high school grade point average (NCES, 2003). The state of West Virginia, through its Higher Education Policy Commission (2002), has applied these same academic performance measures to determine students' placement into developmental/remedial courses in West Virginia two-year and fouryear public higher education institutions. The West Virginia Higher Education Policy Commission (WVHEPC) implemented these standards for freshmen assessment and placement at West Virginia public institutions of higher education. The purpose of these standards is to establish uniform procedures for student placement in credit-bearing courses in mathematics and English (WVHEPC, 2002). By creating the assessment and placement standards for incoming freshmen students to West Virginia institutions of higher education, the WVHEPC provided the means to "assure the integrity of the associate and baccalaureate degrees, to increase the retention and graduation rates of students, and to encourage high school students to improve their academic preparation for college" (WVHEPC, 2002, p. 1). These standards are described below.

\section{Mathematics.}

The minimum standards required of all incoming freshmen students at West Virginia institutions of higher education in mathematics by the WVHEPC's policy "Freshmen Assessment and Placement Standards" include: 
- A score of 19 on the mathematics section of the American College Testing Program's ACT Assessment Test.

- A score of 460 on the quantitative portion of the College Board's Scholastic Assessment (SAT-1).

- A scaled score of 40 on the numerical test and 38 on the elementary algebra test of the American College Testing Program's Assessment of Skills for Successful Entry and Transfer (ASSET).

- A scaled score of 59 on the pre-algebra test and a scaled score of 36 on the algebra test of the American College Testing Program's Computerized Adaptive Placement Assessment and Support System (COMPASS).

- A scaled score of 85 on the arithmetic test and 84 on the elementary algebra test of the College Board's ACCUPLACER Testing System. (pp. 1-2)

\section{English.}

The minimum standards required of all incoming freshmen students at West Virginia institutions of higher education in English by the WVHEPC's policy "Freshmen Assessment and Placement Standards" included:

- A score of 18 on the English section of the ACT.

- A score of 450 on the verbal portion of the SAT-1.

- A scaled score of 38 on the writing skills test of the ASSET.

- A scaled score of 71 on the English Skills test of the American College Testing Program's Computerized Adaptive Placement Assessment and Support System (COMPASS). 
- A scaled score of 88 on the Sentence Skills test of the College Board's ACCUPLACER Testing System.

- Satisfactory performance on a writing sample administered by each institution. (p. 2)

\section{Reading.}

The minimum standards expected of all incoming freshmen students at West Virginia institutions of higher education in reading by the WVHEPC's policy "Freshmen Assessment and Placement Standards" included:

- A score of 17 on the reading section of the ACT

- A score of 420 on the verbal section of the SAT-1

- A score of 36 on the reading skills test of the ASSET

- A score above the 30 percentile on the Nelson-Denny Reading Test

- A scale score of 75 on the reading test of the American College Testing Program's Computerized Adaptive Placement Assessment and Support System (COMPASS)

- A scale score of 79 on the Reading Comprehensive test of the College Board's ACCUPLACER Testing System will be considered to have met minimal reading skill requirements at those institutions which have developmental programs in reading. (p. 3)

Any incoming student that does not meet the minimum standards detailed by the West Virginia Higher Education Policy Commission must enroll in developmental or pre-college level courses and successfully complete the classes before they are able to take mathematics and or English courses that carry credits and count toward a degree (WVHEPC, 2002). However, students that do not meet the reading standards are not required to attend developmental courses. In these cases the institutions of higher education are encouraged to provide assistance to these students to aid them in the pursuit of their degree (WVHEPC, 2002). 


\section{Summary}

This chapter provided a description of developmental education. It provided information on the national and state assessments of the educational systems, research discussing underprepared students and the costs incurred due to developmental and remedial educational programs, the effectiveness of the developmental and remedial educational programs, the assessments of state remediation programs, and the minimum standards required of students entering West Virginia's public institutions of higher education. 


\section{Chapter Three:}

\section{Research Methodology}

The research design that was employed in the study is described in this chapter. It begins with a description of the research method used, then a description of the sample, an account of the data collection and analysis techniques, and concludes with the limitations of the study. The framework of the research design is explained and justifications of the measures used are discussed.

\section{Research Method}

This study examined incoming full-time freshmen students at West Virginia's public four-year institutions of higher education in the 2002 and 2003 cohorts to determine who was required to take developmental educational courses and if those courses had any impact on their degree attainment. As previously discussed, Parks (2001) reported that approximately one-half of college freshmen in West Virginia require some sort of developmental education. This study used a combination of descriptive statistics and quasi-experimental research techniques to address the research questions of the study.

This study provides descriptive statistics (frequency, mean, and proportions) on the demographic makeup and academic preparation level of first-year students taking developmental courses at public four-year institutions compared with students who do not take developmental courses. Descriptive statistics were also used to determine what proportions of students required remediation in the subject areas of reading, English, and mathematics. Quasi-experimental research techniques were used to assess differences in outcomes for students who participated in developmental education while controlling for selection bias. As was previously mentioned, a policy was adopted by the WVHEPC in 2002 that established state-wide minimum scores on 
various tests (ACT, SAT, ASSET, COMPASS) in English, reading, and math that were required to be eligible for placement into college-level courses. Because institutions differ on exactly what they deem to constitute college-level work, each institution has its own set of different expectations and rules that require participation in developmental education. As a result of multiple tests being employed, and because full implementation of this policy was not immediate, there is no one clear cutoff score designating remedial placement and thus the data are inappropriate for a regression discontinuity design study. To compensate for the non-random placement methods in remedial education this study addresses the issue of selection bias through coarsened exact matching (CEM).

Coarsened exact matching is a form of quasi-experimental research that creates a control group and a treatment group with unobserved characteristics that are not systematically related to the outcome of interest, thereby approximating a randomized controlled trial. For the purposes of this study the control group was those students who were not required to take developmental coursework and the treatment group was those students who were required to take developmental coursework.

Coarsened exact matching (CEM) is similar to propensity score matching (PSM), which controls for the pretreatment differences between the treated and the untreated populations by balancing each group's set of observable characteristics, resulting in a propensity score (Reynolds \& DesJardins, 2009; Rosenbaum \& Rubin, 1983). The propensity score in this study would indicate a student's likelihood of being assigned to developmental education. Iacus, King, and Porro (2009), however, raise questions about the outcomes and process of the propensity score matching approach. They argue that propensity score matching is highly model dependent, that balance is typically judged by covariate means rather than the full empirical distribution, that 
coarsening is accomplished through algorithms rather than substantive expertise, and that it requires a laboriously iterative process of checking balance, employing a matching method, and re-checking balance. Thus they recommend coarsened exact matching, which uses simple, fixed, non-overlapping intervals of local indifference, defined ex ante by the researcher based on substantive expertise and the metric of each variable one at a time. (p. 15)

Iacus, King, and Porro (2009) go on to discuss how coarsened exact matching (CEM) is a member of the Monotonic Imbalance Bonding Method (MIB) class of matching:

This means that CEM enables a researcher to choose the maximum imbalance ex ante for each variable on its own (substantively meaningful) scale one at a time, to be certain of the maximum level of multivariate imbalance that will result from the method, and to know that changes in maximum imbalance on one variable does (sic) not affect maximum imbalance on others. The result is that the arduous process of balance checking, tweaking, and repeatedly rerunning the matching procedure is therefore eliminated, as is the uncertainty about whether the matching procedure will improve balance at all. You get what you want rather than getting what you get. (p. 14) Implementing the coarsened exact matching (CEM) requires that the researcher first coarsen continuous variables theorized to predict treatment. In this study the student's composite ACT score and high school GPA, along with other literature supported variables were hypothesized to be related to the likelihood of participating in developmental courses. Iacus, King, and Porro (2009) state that:

The basic idea of CEM is to coarsen each variable by recoding so that substantively indistinguishable values are grouped and assigned the same numerical value (groups may be the same size or different sizes, depending on the substance of the problem). Then the 
"exact matching" algorithm is applied to the coarsened data to determine the matches and to prune unmatched units. Finally, the coarsened data are discarded and the original (uncoarsened) values of the matched data are retained. (p. 21)

With the variables coarsened, students were sorted and matched by strata. In these analyses, multiple matches (rather than one-to-one matches) were allowed for treatment cases and so weights were developed and employed to balance groups. Strata with control and treated cases were retained and strata with control cases only were discarded (Iacus, King, \& Porro, 2009). The original values of the coarsened variables were used in subsequent analysis of the phenomena of interest.

Iacus et al (2009) propose the $\mathcal{L}_{1}$ statistic as a measure of multivariate imbalance, noting it is a better indicator of balance between the treatment and control groups than simple means. They explain that it represents the distance between two multidimensional histograms as measured by the $L^{l}$ norm, where $f$ and $g$ are the relative empirical frequency distributions for the control and treated observations and $f_{\ell_{1}-\ell_{k}}$ as well as $g_{\ell_{1}-\ell_{k}}$ are the relative frequencies for observations in cells with coordinates $\ell_{1} \ldots \ell_{k}$ of the multivariate cross-tabulation.

The $L^{1}$ measure of statistical imbalance

$$
L_{1}(f, g)=\frac{1}{2} \sum_{\ell_{1} \infty \ell_{k} \in H(X)}\left|f_{\ell_{1} \mathrm{~m}}-g_{\ell_{1} \mathrm{~m}}\right|
$$

When $\Sigma_{1}=0$ the two empirical distributions for the control and treated groups overlap entirely, showing perfect balance, whereas $\Sigma_{1}=1$ indicates perfect imbalance or no overlap. Therefore, a lower value indicates greater overlap of the two distributions.

For this study, the retained matched groups were used to address the likelihood of graduation between students who took developmental education courses and similar students 
who did not take any developmental courses; the likelihood of graduation between students who took developmental education courses and passed those courses and similar students who did not take any developmental courses; the relationship between the subject of developmental courses taken and the likelihood of graduation; the time to earn a degree between students who took developmental education courses and similar students who did not take any developmental courses; and time to earn a degree between students who took developmental education courses and passed those courses and similar students who did not take any developmental courses.

\section{Institutional Approval}

The researcher has obtained written approval to use the data provided by the West Virginia Higher Education Policy Commission (Appendix A). The researcher received approval for the study from the West Virginia University Institutional Review Board for the Protection of Human Subjects (IRB) (Appendix B).

\section{Institutional Profiles}

This study examined students from ten public four-year institutions of higher education in West Virginia. The institutions included Bluefield State College, Concord University, Fairmont State University, Glenville State University, Marshall University, Shepherd University, West Liberty University, West Virginia State University, West Virginia University, and WVU Institute of Technology. Table three provides the characteristics of these institutions of higher education. 


\section{Table 3}

Institutional Profiles.

\begin{tabular}{|c|c|c|c|c|c|c|}
\hline Institution & $\begin{array}{c}\text { Total } \\
\text { Enrollment }\end{array}$ & $\begin{array}{l}\text { Degrees } \\
\text { Offered }\end{array}$ & $\begin{array}{c}\text { Total } \\
\text { Degrees } \\
\text { Awarded }\end{array}$ & $\begin{array}{l}\text { Required } \\
\text { ACT Score } \\
\text { for Admin. }\end{array}$ & $\begin{array}{l}\text { Required } \\
\text { H.S. GPA } \\
\text { for Admin. }\end{array}$ & $\begin{array}{c}\text { Cutoff for } \\
\text { Placement in } \\
\text { Dev. Education }\end{array}$ \\
\hline $\begin{array}{l}\text { Bluefield State } \\
\text { College }\end{array}$ & 2,019 & $\begin{array}{l}\text { Bachelor's, } \\
\text { Associate's }\end{array}$ & $30+$ & $\begin{array}{c}18 \text { or } \\
\text { Above }\end{array}$ & $\begin{array}{c}2.0 \text { or } 3.0 \\
\text { with no } \\
\text { ACT Score }\end{array}$ & $\begin{array}{c}\text { Math: Below } 19 \\
\text { English } \\
\text { Below } 18\end{array}$ \\
\hline $\begin{array}{l}\text { Concord } \\
\text { University }\end{array}$ & 2,882 & $\begin{array}{l}\text { Master's, } \\
\text { Bachelor's, } \\
\text { Associate's }\end{array}$ & $70+$ & $\begin{array}{c}18 \text { or } \\
\text { Above }\end{array}$ & $\begin{array}{l}2.0 \text { or } \\
\text { Above }\end{array}$ & $\begin{array}{c}\text { Math: Below } 19 \\
\text { English: } \\
\text { Below } 19\end{array}$ \\
\hline $\begin{array}{l}\text { Fairmont State } \\
\text { University }\end{array}$ & 7,450 & $\begin{array}{l}\text { Master's, } \\
\text { Bachelor's, } \\
\text { Associate's }\end{array}$ & $90+$ & $\begin{array}{c}18 \text { or } \\
\text { Above }\end{array}$ & $\begin{array}{c}2.0 \text { or } 3.0 \\
\text { with no } \\
\text { ACT Score }\end{array}$ & $\begin{array}{c}\text { Math: Below } 18 \\
\text { English: } \\
\text { Below } 18\end{array}$ \\
\hline $\begin{array}{l}\text { Glenville State } \\
\text { College }\end{array}$ & 1,443 & $\begin{array}{l}\text { Bachelor's, } \\
\text { Associate's }\end{array}$ & $30+$ & $\begin{array}{l}18 \text { or } \\
\text { Above }\end{array}$ & $\begin{array}{c}2.0 \text { or } 3.0 \\
\text { with no } \\
\text { ACT Score }\end{array}$ & $\begin{array}{c}\text { Math: Below } 19 \\
\text { English: } \\
\text { Below } 18\end{array}$ \\
\hline $\begin{array}{l}\text { Marshall } \\
\text { University }\end{array}$ & 13,779 & $\begin{array}{l}\text { Doctorate, } \\
\text { Master's, } \\
\text { Bachelor's, } \\
\text { Associate's }\end{array}$ & 104 & $\begin{array}{l}19 \text { or } \\
\text { Above }\end{array}$ & $\begin{array}{l}2.0 \text { or } \\
\text { Above }\end{array}$ & $\begin{array}{c}\text { Math: Below } 19 \\
\text { English: } \\
\text { Below } 18\end{array}$ \\
\hline $\begin{array}{l}\text { Shepherd } \\
\text { University }\end{array}$ & 4,185 & $\begin{array}{l}\text { Master's, } \\
\text { Bachelor's, } \\
\text { Associate's }\end{array}$ & $75+$ & $\begin{array}{c}19 \text { or } \\
\text { Above }\end{array}$ & $\begin{array}{c}2.0 \text { or } 3.0 \\
\text { with no } \\
\text { ACT Score }\end{array}$ & $\begin{array}{c}\text { Math: Below } 19 \\
\text { English: } \\
\text { Below } 18\end{array}$ \\
\hline $\begin{array}{l}\text { West Liberty } \\
\text { University }\end{array}$ & 2,645 & $\begin{array}{l}\text { Master's, } \\
\text { Bachelor's, } \\
\text { Associate's }\end{array}$ & $30+$ & $\begin{array}{c}18 \text { or } \\
\text { Above }\end{array}$ & $\begin{array}{c}2.0 \text { or } 3.0 \\
\text { with no } \\
\text { ACT Score }\end{array}$ & $\begin{array}{c}\text { Math: Below } 19 \\
\text { English: } \\
\text { Below } 18\end{array}$ \\
\hline $\begin{array}{l}\text { West Virginia } \\
\text { State } \\
\text { University }\end{array}$ & 2,500 & $\begin{array}{l}\text { Master's, } \\
\text { Bachelor's, } \\
\text { Associate's }\end{array}$ & $40+$ & $\begin{array}{l}18 \text { or } \\
\text { Above }\end{array}$ & $\begin{array}{c}2.0 \text { or } 3.0 \\
\text { with no } \\
\text { ACT Score }\end{array}$ & $\begin{array}{c}\text { Math: Below } 18 \\
\text { English: } \\
\text { Below } 18\end{array}$ \\
\hline $\begin{array}{l}\text { West Virginia } \\
\text { University }\end{array}$ & 28,839 & $\begin{array}{l}\text { Doctorate, } \\
\text { Master's, } \\
\text { Bachelor's, } \\
\text { Associate's }\end{array}$ & 188 & $\begin{array}{c}\text { 19+ WV } \\
\text { Resident } \\
21+ \\
\text { Nonresident }\end{array}$ & $\begin{array}{c}2.25 \mathrm{WV} \\
\text { Resident } \\
2.5 \\
\text { Nonresident }\end{array}$ & $\begin{array}{c}\text { Math: } \\
\text { Based on QRA } \\
\text { English: } \\
\text { Not Offered }\end{array}$ \\
\hline $\begin{array}{l}\text { WVU Institute } \\
\text { of Technology }\end{array}$ & 1,224 & $\begin{array}{l}\text { Bachelor's, } \\
\text { Associate's }\end{array}$ & 42 & $\begin{array}{l}18 \text { or } \\
\text { Above }\end{array}$ & $\begin{array}{c}2.0 \text { or } 3.0 \\
\text { with no } \\
\text { ACT Score }\end{array}$ & $\begin{array}{c}\text { Math: Below } 19 \\
\text { English: } \\
\text { Below } 19\end{array}$ \\
\hline
\end{tabular}




\section{Population}

This study examined a population of recent high school graduates, who were full-time, first-time, first-year students at the ten public four-year public institutions in West Virginia in the 2002 and 2003 cohorts. Data was obtained from the West Virginia Higher Education Policy Commission (WVHEPC) longitudinal, student-level databases which provided data related to student background variables, high school preparation, term by term enrollment and course taking (including designation of developmental courses), graduation, and yearly financial aid awards. The total population size was 17,168 with students from both years combined.

The focus of this study was on the student population between the years of $18-20$, who were first-time freshmen, and who were not required to take or were required to take developmental education classes at West Virginia's public four-year institutions of higher education. The population of students who had taken developmental education was 4,594 and the population of students who did not take developmental education was 12,574 . The data was prepared so that all information was organized and coded to allow for the coarsened exact matching $(\mathrm{CEM})$ to be conducted to determine the effectiveness of the treatment, in this case taking developmental educational courses.

\section{Data Coding}

The data was organized in subsets and the required data preparation was completed prior to the inferential statistics being conducted. Prior to receiving the data, all of the identifiable information, including names and social security numbers, was removed and replaced with a randomized number. This allowed the researcher to look at the student's personal information without violating their privacy rights while retaining their anonymity. Dummy variables were 
created to distinguish different treatment groups. The following data was collected and was coded as:

\section{Student Demographic Information.}

1. Age: $18-20$ year olds (1), 21 and older (0)

2. Race: White (1), African-American (2), Hispanic (3), Asian, American-Indian or Alaskan-Native (4), Native-Hawaiian or Other Pacific Islander (5)

3. Sex: Male (1) or Female (0)

4. Economic: Disadvantaged (1), Not Disadvantaged (0)

5. Residency Status: In-state (1), Out-of-state (0)

\section{Academic Information.}

6. Year of High School Graduation

7. High School GPA

8. ACT Scores

9. SAT Scores (Converted to ACT scores using SAT/ACT concordance)

10. Degree Earned or Total Hours Earned: Year earned, semester earned, institution earned from, and field of degree earned.

11. Institutional Information: Institutional headcount, institutional percentage admitted, institutional percentage receiving the Pell grant, and institutional tuition and fees.

12. Student Financial Aid Amounts for Freshman Year: State's merit-based PROMISE scholarship, state need-based grants, federal need-based grants, federal work study, institution academic, athletic, and other grants and waivers (e.g., marching band), subsidized loans, and unsubsidized loans. 


\section{Developmental Course Information.}

13. Developmental Class Taken: Course number, year taken, semester taken, numbers of credit hours attached to course, grade earned, and institution where class is taken.

14. Number of Total Developmental Classes Taken: All information included as mentioned above.

\section{Data Analysis}

Table 2 aligns the study's seven research questions with the appropriate research technique. All seven of the research questions were addressed by using quantitative statistics. Data was analyzed using descriptive and inferential statistics. Analysis was performed with PASW Statistics 18 and STATA (to develop the matched pair data sets). Nominal and ordinal variables were analyzed using descriptive statistics (frequencies and percentages). Logistic regression models and ordinary least squares regression models were run on matched pair data sets derived through coarsened exact matching (CEM), as recommended by Iacus, King, and Porro (2009). 


\section{Table 4}

Analysis Techniques for Research Questions.

Methods

1. What is the demographic makeup and academic preparation level of first-year students taking remedial courses at public four-year institutions compared with students who did not take developmental courses?

2. Among the students required to take developmental education courses, what is the proportion of students taking different numbers of developmental classes and students in the subject areas of mathematics, writing, reading, English, and basic skills?

3. Does the likelihood of graduation differ between students who took developmental education courses and similar students who did not take any developmental courses?

4. Does the likelihood of graduation differ between students who took and passed developmental education courses and similar students who did not take any developmental courses?
Proportion of students who are different sex, race, economic disadvantage, residency, and remediation status; mean high school GPA and ACT score.

Proportion of students who took different numbers of developmental courses and who took any courses in each subject.

Matched group of students who did and did not take developmental courses was utilized in a logistic regression model in which the primary independent variable was whether or not a student took developmental education and the outcome variable was whether or not a student graduated with a bachelor's degree within six years.

Matched group of students who took and passed and those who did not take developmental courses was utilized in a logistic regression model in which the primary independent variable was whether or not a student took and passed developmental education courses and the outcome variable was whether or not a student graduated with a bachelor's degree within six years. 
Table 4 (continued)

Analysis Techniques for Research Questions.

Research Questions

5. What is the relationship between the subject of developmental courses taken and the likelihood of graduation?

6. Does time to degree differ between students who took developmental education courses and similar students who did not take any developmental courses?

7. Does time to degree differ between students who took and passed developmental education courses and similar students who did not take any developmental courses?
Methods

Matched group of students who did and did not take each subject of developmental courses (reading, English, writing, and mathematics) was utilized in logistic regression models in which the primary independent variable was whether or not a student took each developmental education subject and the outcome variable was whether or not a student graduated with a bachelor's degree within six years.

Matched group of students who did and did not take developmental courses among those who did graduate was utilized in an ordinary least squares regression model in which the primary independent variable was whether or not a student took developmental education and the outcome variable was the number of academic terms to degree completion.

Matched group of students who took and passed developmental courses and those who did not among those who did graduate was utilized in an ordinary least squares regression model in which the primary independent variable was whether or not a student took and passed developmental education courses and the outcome variable was the number of academic terms to degree completion. 


\section{Limitations of the Study}

The limitations of this study included:

1. This study could not produce the properties of a randomized experiment; therefore, it was necessary to use coarsened exact matching to mimic a true randomized experiment. Although, this study employed a matching procedure to reduce selections bias, the imbalance statistics for the matching process indicated the matches are not perfect and some selection bias still exists.

2. This study could not address all factors that might cause a student to withdraw from college.

3. This study examined West Virginia's higher education institutions due to the researcher having access to this State's data and because West Virginia is recognized nationally for having a student population that finishes in the bottom of national rankings in education.

4. While this study was limited in that it drew on data from only one state, it added another state to the growing list of those where rigorous evaluative studies of developmental studies have occurred, Bettinger and Long (2005) for Ohio, Martorell and McFarlin (2007) for Texas, and Calcagno and Long (2008) for Florida.

5. The study was also limited in its analysis of only recent high school graduates.

\section{Summary}

Chapter three described the research design that was employed in the study. The research design for this study was a quantitative research study that used descriptive statistics as well as coarsened exact matching. The procedures, population, data collection, data coding, data analysis, and limitations were discussed. Data used for this study were provided by the West Virginia Higher Education Policy Commission. The population for this study was identified as 
the 17,168 recent high school graduates who were full-time, first-time, first-year students at the ten public four-year public institutions in West Virginia in the 2002 and 2003 cohorts. The population of students who had taken developmental education was 4,594 and the population of students who did not take developmental education was 12,574. Of the seven research questions, two employed descriptive statistics and five employed coarsened exact matching to prepare data sets for logistic and linear regression. 


\section{Chapter Four:}

\section{Findings}

This chapter presents the detailed findings and results of the research study. The first section of the chapter presents the demographic and academic characteristics of the students in the sample. The next seven sections address each research question and report the study's findings. The research questions were:

1. What is the demographic makeup and academic preparation level of first-year students taking remedial courses at public four-year institutions compared with students who do not take developmental courses?

2. Among the students required to take developmental education courses, what is the proportion of students who took different numbers of developmental classes and of students in the subject areas of mathematics, writing, reading, English, and basic skills?

3. Does the likelihood of graduation differ between students who took developmental education courses and similar students who did not take any developmental courses?

4. Does the likelihood of graduation differ between students who took and passed developmental education courses and similar students who did not take any developmental courses?

5. What is the relationship between the subject of developmental courses taken and the likelihood of graduation?

6. Does time to degree differ between students who took developmental education courses and similar students who did not take any developmental courses?

7. Does time to degree differ between students who took and passed developmental education courses and similar students who did not take any developmental courses? 


\section{Descriptive Statistics}

The population of the study was 17,168 recent high school graduates who were first-time, full-time freshmen at the ten public four-year public institutions in West Virginia in the 2002 and 2003 cohorts. The student population was between the years of 18-20 and included students who were required to take developmental education and who were not required to take developmental education. The proportion of students who differed by race, sex, institutions attended, were economically disadvantaged, were in-state students, and took developmental education courses were all examined for the total population.

The majority of this population was white $(92.6 \%)$, which was expected due to the lack of ethnic diversity in West Virginia. Of the total population, 4.7 percent were African-American students. Hispanic students (1.1\%), Asian/Pacific Islander students (1.3\%), and American Indian/Alaskan Native students $(0.2 \%)$ made up less than three percent of the total population (see Table 5).

Table 5

Race.

\begin{tabular}{lcc}
\hline Race & Number of Students & Percentage of Students \\
\hline \hline White & 15,897 & $92.6 \%$ \\
African-American & 808 & $4.7 \%$ \\
Hispanic & 194 & $1.1 \%$ \\
Asian/Pacific Islander & 227 & $1.3 \%$ \\
American Indian/Alaskan Native & 42 & $0.2 \%$ \\
Total Population & 17,168 & $100 \%$ \\
\hline
\end{tabular}


The population was comprised of nearly half female (50.7\%) and half male (49.3\%) students (see Table 6).

\section{Table 6}

Sex.

\begin{tabular}{lcc}
\hline Sex & Number of Students & Percentage of Students \\
\hline Male & 8,465 & $49.3 \%$ \\
Female & 8,703 & $50.7 \%$ \\
Total Population & 17,168 & $100 \%$ \\
\hline
\end{tabular}

Nearly half (47.3\%) of the student population attended West Virginia University. This finding was expected because it is the state's flagship university and is the largest higher education institution in the state. Of the population, 20.6\% attended Marshall University, 6.7\% attended Fairmont State University, 6.3\% attended Shepherd University, and 6.4\% attended Concord University. Of the total population, $12.7 \%$ of students attended the six other institutions included in this study (see Table 7).

Table 7

Institution Attended.

\begin{tabular}{lcc}
\hline Institutions & Number of Students & Percentage of Students \\
\hline Bluefield State College & 76 & $0.4 \%$ \\
Concord University & 1,101 & $6.4 \%$ \\
Fairmont State University & 1,150 & $6.7 \%$ \\
Glenville State College & 416 & $2.4 \%$ \\
Marshall University & 3,530 & $20.6 \%$ \\
Shepherd University & 1,076 & $6.3 \%$ \\
West Liberty University & 719 & $4.2 \%$ \\
West Virginia State University & 538 & $3.1 \%$ \\
West Virginia University & 8,112 & $47.3 \%$ \\
West Virginia University Institute of Technology & 450 & $2.6 \%$ \\
Total Population & 17,168 & $100 \%$ \\
\hline
\end{tabular}


Table 8 describes the proportion of students who were economically disadvantaged (23.8\%), their residency status $(67.3 \%$ in-state), and the number of students taking developmental education courses (26.8\%). As previously mentioned, Parks (2001) reported that approximately one-half of all college freshmen in West Virginia require developmental education. This study examines students who attended four-year institutions, excluding those students who attended two-year institutions and who were more likely to require developmental education. Furthermore, this study only includes recent high school graduates, excluding those students who were not recent high school graduates and who also were more likely to required developmental education. Thus, the number of students requiring developmental education is lower in the population than what was reported in previous research.

\section{Table 8}

Other Characteristics.

\begin{tabular}{lcc}
\hline Characteristics & Number of Students & Percentage of Students \\
\hline \hline Economically Disadvantaged & 4,082 & $23.8 \%$ \\
In-State & 11,561 & $67.3 \%$ \\
Took Developmental Courses & 4,594 & $26.8 \%$ \\
\hline
\end{tabular}

Table 9 provides the mean for both high school grade point average and ACT scores (with student SAT score converted to ACT score). Students in this population had a mean high school grade point average of 3.25 and a mean ACT score of 21.81. Of the total population, $50.5 \%$ graduated within six years, taking an average of 12.86 semesters to graduate.

\section{Table 9}

High School Grade Point Average and ACT Scores.

\begin{tabular}{lc}
\hline H.S. GPA and ACT & Student Scores \\
\hline \hline High School Grade Point Average & 3.25 \\
ACT Scores & 21.81 \\
\hline
\end{tabular}




\section{Research Question One}

The first research question asked: What is the demographic makeup and academic preparation level of first-year students taking remedial courses at public four-year institutions compared with students who do not take developmental courses? This research question was answered by calculating the proportion of students who differed by race, sex, institution attended, economic disadvantage status, residency status, if they require remediation, mean high school grade point average, and the mean ACT score.

To address the research question for the study, the population $(\mathrm{N}=17,168)$ was divided into two groups, those students who took developmental education courses (4,594 students) and those students who did not take developmental education courses (12,574 students). Of the total population that took developmental education coursework, $89.6 \%$ were white, $8.6 \%$ were African-American, $0.01 \%$ were Hispanic, $0.01 \%$ were Asian/Pacific Islander, and $0.01 \%$ were American Indian/Alaskan Native (See Table 10). The majority of this population that took developmental education courses was white, which is consistent with the findings of the total population where the majority of the population was white $(92.6 \%)$. Due to the small proportions of other minority populations, only a dummy variable for African-American students was included in the subsequent inferential analyses.

\section{Table 10}

Race of Students that Took Developmental Education.

\begin{tabular}{lcc}
\hline Race & Number of Students & Percentage of Students \\
\hline \hline White & 4,116 & $89.6 \%$ \\
African-American & 395 & $8.6 \%$ \\
Hispanic & 44 & $0.01 \%$ \\
Asian/Pacific Islander & 28 & $0.01 \%$ \\
American Indian/Alaskan Native & 11 & $0.01 \%$ \\
Total Students that took Dev. Ed & 4,594 & $100 \%$ \\
\hline
\end{tabular}


Of these students that took developmental education coursework, $44.1 \%$ were males and $55.9 \%$ were females (See Table 11). This is different from the findings from the population which was comprised of nearly half female (50.7\%) and half male (49.3\%) students.

\section{Table 11}

Sex of Students that Took Developmental Education.

\begin{tabular}{lcc}
\hline Sex & Number of Students & Percentage of Students \\
\hline Male & 2,027 & $44.1 \%$ \\
Female & 2,567 & $55.9 \%$ \\
Total Students that took Dev. Ed & 4,594 & $100 \%$ \\
\hline
\end{tabular}

The largest number of students $(1,486)$ who took developmental education courses at a single institution attended Marshall University (see Table 12). Although, nearly half (47.3\%) of the total student population of the study $(17,168)$ attended West Virginia University, only 162 students or two percent of these students took developmental education courses there. West Virginia University has the highest required ACT score for admission in the state and does not offer many developmental education courses. West Virginia University requires students to take developmental education courses at two-year institutions and/or at other institutions prior to admitting these students on campus. The largest proportion of students that took developmental education courses at a single university was at Glenville State College. At Glenville State College $98.1 \%$ of students were required and took developmental education coursework at some point during their time at that institution. This high percentage of students required to take developmental education is due to Glenville State College requiring all first-time freshman students to take an introduction course to college (University 101) that is coded as a developmental education course. 


\section{Table 12}

Percentage of Students that Took Developmental Education by Institution.

\begin{tabular}{lccc}
\hline Institutions & $\begin{array}{c}\text { Number of } \\
\text { Students by } \\
\text { Institution }\end{array}$ & $\begin{array}{c}\text { Number of } \\
\text { Students that } \\
\text { Took Dev. Ed }\end{array}$ & $\begin{array}{c}\text { Percentage of } \\
\text { Students that } \\
\text { Took Dev. Ed }\end{array}$ \\
\hline \hline Bluefield State College & 76 & 43 & $56.6 \%$ \\
Concord University & 1,101 & 559 & $50.8 \%$ \\
Fairmont State University & 1,150 & 581 & $50.5 \%$ \\
Glenville State College & 416 & 408 & $98.1 \%$ \\
Marshall University & 3,530 & 1,486 & $42.1 \%$ \\
Shepherd University & 1,076 & 411 & $38.2 \%$ \\
West Liberty University & 719 & 369 & $51.3 \%$ \\
West Virginia State University & 538 & 387 & $71.9 \%$ \\
West Virginia University & 8,112 & 162 & $2.0 \%$ \\
WV University Institute of Technology & 450 & 188 & $41.7 \%$ \\
Total & 17,168 & 4,594 & $26.8 \%$ \\
\hline
\end{tabular}

Table 13 describes the proportion of students who took developmental education and were economically disadvantaged (45.5\%) and their residency status ( $82.9 \%$ in-state). These findings were higher than the proportion of students in the total population who were economically disadvantaged (23.8\%) and in-state students $(67.3 \%$ in-state).

Table 13

Other Characteristics of Students that Took Developmental Education.

\begin{tabular}{lcc}
\hline Characteristics & Number of Students & Percentage of Students \\
\hline Economically Disadvantaged & 2,089 & $45.5 \%$ \\
In-State & 3,810 & $82.9 \%$ \\
\hline
\end{tabular}

Table 14 provides the means for both high school grade point average and ACT scores. Those students who were required to take developmental education had a grade point average of 3.03 and an 18.97 ACT score compared to 3.32 grade point average and a 22.85 ACT score for students who did not take developmental education. 


\section{Table 14}

Comparison of Students that Took and Did Not Take Developmental Education High School Grade Point Average and ACT Scores.

\begin{tabular}{lcc}
\hline H.S. GPA and ACT & Took Dev. Ed & Did Not Take Dev Ed \\
\hline \hline High School Grade Point Average & 3.03 & 3.32 \\
ACT Scores & 18.97 & 22.85 \\
\hline
\end{tabular}

Table 15 describes the demographic profile of those students who took developmental education and those students who did not take developmental education. Students taking developmental courses were more likely to have delayed enrollment past the fall immediately following high school graduation, and to have lower high school GPAs and composite ACT scores. These students tended to be at institutions with lower tuition and fees. Students who took developmental courses attended institutions that had a higher proportion of Pell recipient students.

In terms of aid, developmental education students had lower average levels of the state's merit-based PROMISE scholarship, institution academic and other grants and waivers, federal work study, subsidized loans, and unsubsidized loans than students who did not take developmental courses. Students who took developmental education courses had higher average values of state need-based aid, federal need-based grant aid, and institution athletic grants and waivers. In general, developmental education students received more need-based aid and earned less merit-based aid.

Finally, far fewer students who took developmental courses graduated within the six-year window (33.3\%) as compared with those who do not take developmental courses (56.8\%). Of those students who did graduate, students who took developmental education courses took approximately one term longer to graduate. The descriptive information shows not only that 
graduation and time to degree outcomes differ by remediation status but also that students receiving remediation are different in other ways than those who do not participate in developmental education courses.

Table 15

Comparison Descriptive Information.

\begin{tabular}{|c|c|c|c|}
\hline \multirow[b]{2}{*}{ Variable } & \multicolumn{3}{|c|}{ Percentage/Mean } \\
\hline & $\begin{array}{l}\text { Did Not Take } \\
\text { Dev. Courses }\end{array}$ & $\begin{array}{c}\text { Took Dev. } \\
\text { Courses }\end{array}$ & $\begin{array}{c}\text { Full } \\
\text { Population }\end{array}$ \\
\hline $\mathrm{N}$ & 12,574 & 4,594 & 17,168 \\
\hline Male & $51.2 \%$ & $44.1 \%$ & $49.3 \%$ \\
\hline African-American & $3.3 \%$ & $8.6 \%$ & $4.7 \%$ \\
\hline In-State Resident & $61.6 \%$ & $82.9 \%$ & $67.3 \%$ \\
\hline Economically Disadvantaged & $15.9 \%$ & $45.5 \%$ & $23.8 \%$ \\
\hline Delayed Enrollment & $2.3 \%$ & $5.7 \%$ & $3.2 \%$ \\
\hline High School GPA & 3.32 & 3.03 & 3.25 \\
\hline Composite ACT & 22.85 & 18.97 & 21.81 \\
\hline Institution Tuition and Fees & $\$ 3,284$ & $\$ 3,049$ & $\$ 3,221$ \\
\hline Institution Percent Admitted & $88.4 \%$ & $84.0 \%$ & $87.2 \%$ \\
\hline Institution Percent Pell & $29.0 \%$ & $39.4 \%$ & $31.8 \%$ \\
\hline PROMISE Scholarship & $\$ 1,247$ & $\$ 441$ & $\$ 1,031$ \\
\hline State Need-Based Aid & $\$ 284$ & $\$ 459$ & $\$ 331$ \\
\hline Federal Need-Based Aid & $\$ 704$ & $\$ 1,184$ & $\$ 832$ \\
\hline Federal Work Study & $\$ 72$ & $\$ 65$ & $\$ 70$ \\
\hline Academic Grants and Waivers & $\$ 645$ & $\$ 206$ & $\$ 528$ \\
\hline Athletic Grants and Waivers & $\$ 206$ & $\$ 262$ & $\$ 221$ \\
\hline Other Grants and Waivers & $\$ 117$ & $\$ 34$ & $\$ 95$ \\
\hline Subsidized Loans & $\$ 947$ & $\$ 860$ & $\$ 924$ \\
\hline Unsubsidized Loans & $\$ 753$ & $\$ 598$ & $\$ 711$ \\
\hline Graduated in Six Years & $56.8 \%$ & $33.3 \%$ & $50.5 \%$ \\
\hline Terms to Graduation* & 12.61 & 13.98 & 12.86 \\
\hline
\end{tabular}

*Among those who graduated.

\section{Research Question Two}

The second research question asked: Among the students required to take developmental education courses, what is the proportion of students who took different numbers of developmental classes and of students in the subject areas of mathematics, writing, reading, 
English, and basic skills? The analysis was performed by calculating the proportion of students taking different numbers of developmental courses and calculating the proportion of students taking developmental courses in each subject area.

To address the research question for the study, the population $(\mathrm{N}=17,168)$ was divided into two groups- those students who took developmental education (4,594 students) and those students who did not take developmental education (12,574 students). Some students required only one developmental class $(29.2 \%)$. However, in many cases the students who took developmental education required more than one developmental class $(70.8 \%)$. The majority of the students who were required to take developmental education courses took two courses $(34.5 \%)$. The largest number of developmental courses taken by one student was eighteen. Table 16 shows the number of students taking developmental courses and the percentage of those students in the total population and in the population of students who took developmental education courses. The findings include students who took a developmental course, failed that course, and retook the same course.

\section{Table 16}

Number of Developmental Courses Taken.

\begin{tabular}{lccc}
\hline $\begin{array}{l}\text { Number of Developmental } \\
\text { Courses Taken }\end{array}$ & Number of Students & $\begin{array}{c}\text { \% of Total } \\
\text { Population }\end{array}$ & $\begin{array}{c}\text { \% of Dev. } \\
\text { Students }\end{array}$ \\
\hline \hline Zero & 12,561 & $73.2 \%$ & $0 \%$ \\
One & 1,343 & $7.8 \%$ & $29.2 \%$ \\
Two & 1,586 & $9.2 \%$ & $34.5 \%$ \\
Three & 774 & $4.5 \%$ & $16.8 \%$ \\
Four & 484 & $2.8 \%$ & $10.5 \%$ \\
Five & 200 & $1.2 \%$ & $4.3 \%$ \\
Six & 98 & $0.6 \%$ & $2.1 \%$ \\
Seven & 42 & $0.2 \%$ & $0.9 \%$ \\
Eight or more classes & 80 & $0.5 \%$ & $1.7 \%$ \\
\hline
\end{tabular}


Out of the number of the students who took developmental education (4,594 students), the proportion taking courses in the area of developmental math was $83.8 \%$, in developmental writing was $24.9 \%$, in developmental reading $6.1 \%$, in developmental English $10.9 \%$, and in developmental basic skills $41.1 \%$ (see Table 17). The largest proportion of students for this study required remediation in developmental mathematics, which is consistent with previous research (NCES 2003 \& NCES 1996). These findings include students who were required to take more than one developmental course subject.

\section{Table 17}

\section{Students who Took Developmental Education Subject Area.}

\begin{tabular}{lccc}
\hline $\begin{array}{c}\text { Developmental } \\
\text { Subject }\end{array}$ & $\begin{array}{c}\text { Number of Students } \\
\text { Taking Dev. Courses }\end{array}$ & $\begin{array}{c}\text { Percentage of } \\
\text { Students in Population } \\
(\mathrm{N}=17,168)\end{array}$ & $\begin{array}{c}\text { Percentage of } \\
\text { Students Taking } \\
\text { Dev. Ed. (N=4,594) }\end{array}$ \\
\hline \hline Dev. Math & 3,852 & $22.4 \%$ & $83.8 \%$ \\
Dev. Writing & 1,143 & $6.7 \%$ & $24.9 \%$ \\
Dev. Reading & 279 & $1.6 \%$ & $6.1 \%$ \\
Dev. English & 504 & $2.9 \%$ & $10.9 \%$ \\
Dev. Basic Skills & 1,888 & $10.9 \%$ & $41.1 \%$ \\
Total & 4,594 & $26.7 \%$ & $100 \%$ \\
\hline
\end{tabular}

As previously discussed, some of the students took classes in more than one developmental course, and in some instances, took courses in more than one developmental subject area. At Fairmont State University, students who were enrolled in developmental math courses were also required to take developmental basic skills courses. Table 18 shows the percentage of those students who took various combinations of developmental subjects. For example, of those who took developmental math (in row one), 22 percent also took writing, 5.1 percent took reading, 9.2 percent took English, and 35.6 percent took basic skills. 


\section{Table 18}

Percentage of Students Who Took a Developmental Subject and Also Needed To Take a Different Developmental Subject.

\begin{tabular}{|c|c|c|c|c|c|}
\hline $\begin{array}{l}\text { Developmental } \\
\text { Subject }\end{array}$ & Dev. Math & Dev. Writing & Dev. Reading & Dev. English & $\begin{array}{c}\text { Dev. Basic } \\
\text { Skills }\end{array}$ \\
\hline $\begin{array}{l}\text { Dev. Math and } \\
\text { Different Dev. } \\
\text { Subject }\end{array}$ & $100 \%$ & $22 \%$ & $5.1 \%$ & $9.2 \%$ & $35.6 \%$ \\
\hline $\begin{array}{l}\text { Dev. Writing and } \\
\text { Different Dev. } \\
\text { Subject }\end{array}$ & $74.1 \%$ & $100 \%$ & $13.4 \%$ & $3.4 \%$ & $28.3 \%$ \\
\hline $\begin{array}{l}\text { Dev. Reading } \\
\text { and Different } \\
\text { Dev. Subject }\end{array}$ & $70.3 \%$ & $54.8 \%$ & $100 \%$ & $20.4 \%$ & $12.5 \%$ \\
\hline $\begin{array}{l}\text { Dev. English and } \\
\text { Different Dev. } \\
\text { Subject }\end{array}$ & $70.2 \%$ & $7.7 \%$ & $11.3 \%$ & $100 \%$ & $5.2 \%$ \\
\hline $\begin{array}{l}\text { Dev. Basic Skill } \\
\text { and Different } \\
\text { Dev. Subject }\end{array}$ & $72.7 \%$ & $17.2 \%$ & $1.9 \%$ & $1.4 \%$ & $100 \%$ \\
\hline
\end{tabular}

\section{Research Questions Three-Seven}

To answer research questions three, four, five, six, and seven the researcher examined the total population $(\mathrm{N}=17,168)$ of first-time, recent high school graduates (within 18 months of matriculation), first-year students at the ten four-year public institutions in West Virginia in the falls of 2002 and 2003. Since multiple tests were used to determine developmental education placement, and because full implementation of the West Virginia Higher Education Policy Commission policy on minimum scores was not immediate, there was no one clear score cutoff designating developmental education placement. This study addressed the issue of selection bias through coarsened exact matching (CEM). Research questions three, four, five, six and seven 
were all answered using the quasi-experimental research technique coarsened exact matching to address selection bias.

In these analyses, two different matching processes took place to assess the effects of two different conceptualizations of remediation. The first matching process created matched sets of students who participated in any developmental courses versus those who did not take any developmental courses. These matched sets were used to answer research questions three, five, and six. The second matching process created matched sets of students who participated in and passed their developmental courses versus those students who did not take any developmental courses. The students' grades were analyzed in each of their developmental courses. Students were classified as passing all of their developmental courses if they passed each of them on the first try, if they initially failed a course but retook and passed that same exact course, or if they failed a course and then took a different course in that same subject and passed it at that institution or another in the system. Some institutions required grades higher than simply passing, such as at least a $\mathrm{C}$, in order to move up to the next level. At these institutions, students were counted as passing only if they achieved that higher minimum grade. The second matched sets were used to answer research questions four and seven.

To answer these questions, data were examined that included information about student background, academic preparation, institutional attended, and financial aid received. The target variables in the study describe whether a student took developmental courses (see Table 19). Courses were identified as developmental if they had particular Classification of Instructional Programs (CIP) codes. These students were followed for six years after initial matriculation to see if they completed their degree. To prevent multi-collinearity, correlations of the variables predicted to influence the likelihood of graduation were examined prior to inclusion in the study. 
This step assured that the findings would be valid and not skewed due to items that were highly correlated and influencing the results. If the variables were highly correlated with the other variables, they were eliminated from the study. This study used the cutoff Pearson correlation score of 0.60 ; less than 0.60 was deemed acceptable.

\section{Table 19}

Variables Included in the Study by Conceptual Blocks.

\begin{tabular}{|c|c|c|c|}
\hline $\begin{array}{c}\text { Student } \\
\text { background }\end{array}$ & $\begin{array}{l}\text { Academic } \\
\text { preparation }\end{array}$ & Institutional context & $\begin{array}{l}\text { Financial aid } \\
\text { (in } \$ 1000 \text { s) }\end{array}$ \\
\hline Race/Ethnicity & $\begin{array}{l}\text { High School } \\
\text { GPA }\end{array}$ & Institution Headcount & $\begin{array}{l}\text { PROMISE } \\
\text { scholarship }\end{array}$ \\
\hline Gender & $\begin{array}{l}\text { Composite ACT } \\
\text { score }\end{array}$ & $\begin{array}{l}\text { Institution Percent } \\
\text { Admitted }\end{array}$ & $\begin{array}{l}\text { State Need-based } \\
\text { Aid }\end{array}$ \\
\hline Late & & Institution Percent Pell & \\
\hline Enrollment & $\begin{array}{l}\text { Took Dev. } \\
\text { Courses }\end{array}$ & & $\begin{array}{l}\text { Federal Need- } \\
\text { Based Aid }\end{array}$ \\
\hline In-state student & $\begin{array}{l}\text { Took and passed } \\
\text { all Dev. Courses }\end{array}$ & $\begin{array}{l}\text { Semester tuition and } \\
\text { fees }\end{array}$ & $\begin{array}{l}\text { Institutional } \\
\text { athletic grants and } \\
\text { waivers }\end{array}$ \\
\hline $\begin{array}{l}\text { Economic } \\
\text { Disadvantage }\end{array}$ & & & $\begin{array}{l}\text { Institutional } \\
\text { academic grants } \\
\text { and waivers }\end{array}$ \\
\hline & & & $\begin{array}{l}\text { Federal work study } \\
\text { Institutional other } \\
\text { grants and waivers }\end{array}$ \\
\hline & & & Subsidized loans \\
\hline & & & Unsubsidized loans \\
\hline
\end{tabular}




\section{Research Question Three}

The third research question asked: Does the likelihood of graduation differ between students who took developmental education courses and similar students who did not take any developmental courses? The findings were significant and showed that students that took developmental education courses were less likely to graduate than students who are similar and did not take developmental education courses.

To answer the research question, a matched group of students who did and did not take developmental courses was utilized in a logistic regression model in which the primary independent variable was whether or not a student took developmental education and the outcome variable was whether or not a student graduated with a bachelor's degree within six years. Of the total population $(17,168), 12,171$ students were matched. The matched group consisted of 8,912 students who did not take any developmental education courses and 3,390 students who took developmental education courses. The unmatched $\mathcal{L}_{1}$ statistic was .804 and matching resulted in an $\mathcal{L}_{1}$ of .618 for a 23 percent reduction in imbalance. These matched groups were utilized in a logistic regression model to determine the effect developmental education had on a student's likelihood of graduation. Coefficients are expressed as exponentiated beta or odds ratios.

As was previously mentioned, examining the variable of interest, it can be seen that the coefficient for taking developmental courses is significant and that taking developmental courses did not increase the likelihood of graduating. Students who took developmental education courses were less likely to graduate than students who are similar and did not take developmental education courses (see Table 20). The Nagelkerke $\mathrm{R}^{2}$ for this model is 0.193 with 67.9 percent of cases assigned correctly. The Nagelkerke $\mathrm{R}^{2}$ is a Pseudo $\mathrm{R}^{2}$. Like the $\mathrm{R}^{2}$ it is the square of the 
correlation between the model's predicted values and the actual values. The Nagelkerke $\mathrm{R}^{2}$ generalizes the definition of the coefficient of determination.

Table 20

Likelihood of Graduation for Students Who Did and Did Not Take Developmental Courses.

\begin{tabular}{|c|c|c|c|c|}
\hline \multirow{2}{*}{$\begin{array}{l}\text { Variables in the Equation } \\
\text { Background }\end{array}$} & $\operatorname{Exp}(B)$ & \multicolumn{2}{|l|}{ Sig. } & \multirow[t]{2}{*}{ S.E. } \\
\hline & & & & \\
\hline Male & 1.075 & 0.097 & & 0.044 \\
\hline African-American & 0.893 & 0.427 & & 0.142 \\
\hline In-State & 0.632 & 0 & ** & 0.069 \\
\hline Economic Disadvantage & 0.692 & 0 & ** & 0.047 \\
\hline \multicolumn{5}{|l|}{ Academic Preparation } \\
\hline High School GPA & 4.47 & 0 & ** & 0.058 \\
\hline Composite ACT score & 0.997 & 0.776 & & 0.01 \\
\hline Late Enrollment & 0.509 & 0 & ** & 0.187 \\
\hline Took Developmental Ed. & 0.794 & 0 & $* *$ & 0.056 \\
\hline \multicolumn{5}{|l|}{ Institutional Context } \\
\hline Institution Percent Admitted & 1.016 & 0 & $* *$ & 0.003 \\
\hline Institution Percent Pell & 1.007 & 0 & ** & 0.002 \\
\hline Institution Headcount & 1.016 & 0 & $* *$ & 0.004 \\
\hline Tuition and Fees & 0.767 & 0.038 & $*$ & 0.128 \\
\hline \multicolumn{5}{|l|}{ Financial Aid (in $\$ 1000$ s) } \\
\hline Academic grants and waivers & 1.078 & 0.082 & & 0.043 \\
\hline Athletic grants and waivers & 1.091 & 0 & ** & 0.019 \\
\hline Other grants and waivers & 1.281 & 0 & ** & 0.062 \\
\hline PROMISE scholarship & 1.118 & 0 & $* *$ & 0.021 \\
\hline State Need-Based Aid & 1.159 & 0 & $* *$ & 0.027 \\
\hline Federal Need-Based Aid & 0.869 & 0 & $* *$ & 0.016 \\
\hline Federal work study & 1.459 & 0 & ** & 0.077 \\
\hline Subsidized loans & 0.99 & 0.582 & & 0.017 \\
\hline Unsubsidized loans & 0.994 & 0.664 & & 0.015 \\
\hline Constant & 0.004 & 0 & & 0.589 \\
\hline The Nagelkerke $R^{2} .193$ & & & & \\
\hline
\end{tabular}

*Significant at less than $0.05 \quad * *$ Significant at less than 0.01

Other variables were included in the analysis although they were not the variables of interest for research question three. Although these variables are not directly related to research 
question three, they do provide insight into other areas that shape the likelihood of a student graduating within six years. The variables that were significant, and found to lessen the likelihood of the matched student group to graduate within six years included:

- Being a resident of West Virginia, economically disadvantaged, or a late enrollment student (not starting the fall semester after high school graduation); and,

- Attending an institution with higher tuition and fees, and receiving an additional thousand dollars in federal need-based aid.

Variables that were significant and were found to increase the likelihood of the matched student group to graduate within six years included:

- Having a higher high school grade point average;

- Attending an institution that had a higher enrollment, a higher percentage of students admitted, or a higher percentage of students receiving a Pell grant; and

- Receiving institutional athletic grants or waivers, other institutional grants or waivers, state need-based aid, and federal work study.

\section{Research Question Four}

Research question four asked: Does the likelihood of graduation differ between students who took and passed developmental education courses and similar students who did not take any developmental courses? The findings were not significant and showed that taking and passing developmental education courses did not have an effect on the likelihood of graduation when compared with similar students that did not take developmental education courses

To answer the research question a matched sample of students who took and passed developmental education courses and those who did not take developmental education courses. 
was utilized in a logistic regression model in which the primary independent variable was whether or not a student took and passed developmental education courses and the outcome variable is whether or not a student graduated with a bachelor's degree within six years. Of the total population $(\mathrm{N}=17,168), 11,063$ students were matched. The matched group consisted of 8,661 students who did not take any developmental education courses and 2,402 students who took and passed their developmental education courses. The unmatched $\mathcal{L}_{1}$ statistic was .814 and matching resulted in an $\mathcal{L}_{1}$ of .644 for a 21 percent reduction in imbalance. These matched groups were utilized in a logistic regression model to determine the effect passing developmental education had on a student's likelihood of graduation. Coefficients are expressed as exponentiated beta or odds ratios.

As previously discussed, in examining the matched group of students who took and passed developmental education courses and those who did not take developmental education courses, the data indicate no significant difference in the likelihood of graduation. Whereas students simply taking developmental courses had lower rates of graduation, those who took developmental courses and passed them all were neither more nor less likely to graduate with a bachelor's degree within six years (see Table 21). Taking and passing developmental education courses resulted in a graduation rate similar to students who did not take developmental education courses. The Nagelkerke $\mathrm{R}^{2}$ for this model was 0.179 with 65.8 percent of cases assigned correctly. 


\section{Table 21}

Likelihood of Graduation for Students Who Took and Passed Developmental Courses and for Students Who Did Not Take Developmental Courses.

\begin{tabular}{|c|c|c|c|c|}
\hline \multirow{2}{*}{$\begin{array}{l}\text { Variables in the Equation } \\
\text { Background }\end{array}$} & \multirow[t]{2}{*}{$\operatorname{Exp}(B)$} & \multicolumn{2}{|c|}{ Sig. } & \multirow[t]{2}{*}{ S.E. } \\
\hline & & & & \\
\hline Male & 1.088 & 0.064 & & 0.046 \\
\hline African-American & 0.622 & 0.001 & $* *$ & 0.148 \\
\hline In-State & 0.68 & 0 & ** & 0.073 \\
\hline Economic Disadvantage & 0.741 & 0 & $* *$ & 0.048 \\
\hline \multicolumn{5}{|l|}{ Academic Preparation } \\
\hline High School GPA & 4.019 & 0 & $* *$ & 0.061 \\
\hline Composite ACT score & 1.02 & 0.053 & & 0.01 \\
\hline Late Enrollment & 0.659 & 0.015 & $* *$ & 0.172 \\
\hline Took Developmental Education & 1.044 & 0.396 & & 0.051 \\
\hline \multicolumn{5}{|l|}{ Institutional Context } \\
\hline Institution Percent Admitted & 1.018 & 0 & $* *$ & 0.003 \\
\hline Institution Percent Pell & 1.007 & 0 & ** & 0.002 \\
\hline Institution Headcount & 1.017 & 0 & ** & 0.004 \\
\hline Tuition and Fees & 0.708 & 0.009 & ** & 0.132 \\
\hline \multicolumn{5}{|l|}{ Financial Aid (in \$1000s) } \\
\hline Academic grants and waivers & 1.135 & 0.004 & $* *$ & 0.044 \\
\hline Athletic grants and waivers & 1.062 & 0.004 & $* *$ & 0.021 \\
\hline Other grants and waivers & 1.234 & 0.002 & $* *$ & 0.067 \\
\hline PROMISE scholarship & 1.073 & 0.001 & $* *$ & 0.022 \\
\hline State Need-Based Aid & 1.262 & 0 & $* *$ & 0.028 \\
\hline Federal Need-Based Aid & 0.847 & 0 & ** & 0.017 \\
\hline Federal work study & 1.51 & 0 & $* *$ & 0.082 \\
\hline Subsidized loans & 0.941 & 0.001 & $* *$ & 0.018 \\
\hline Unsubsidized loans & 0.969 & 0.031 & * & 0.014 \\
\hline Constant & 0.004 & 0 & & 0.618 \\
\hline
\end{tabular}

*Significant at less than $0.05 \quad * *$ Significant at less than 0.01

Other variables were included in the analysis although they were not the variables of interest for research question four. The variables that were significant, and found to lessen the likelihood of the matched student group to graduate within six years included: 
- Being an African-American student, a resident of West Virginia, economically disadvantaged, or a late enrollment student (not starting the fall semester after high school graduation);

- Attending an institution with higher tuition and fees; and

- Receiving federal need-based aid, subsidized loans, or unsubsidized loans.

Variables that were found to be significant and increase the likelihood of the matched student group to graduate within six years included:

- Having a higher high school grade point average;

- Attending an institution that had a higher percentage of students admitted, a higher percentage of student enrollment, or a higher percentage of students receiving a Pell grant; and

- Receiving institutional academic grants or waivers, athletic grants or waivers, other institutional grants or waivers, PROMISE scholarship, state need-based aid, or federal work study.

\section{Research Question Five}

Research question five asked: What is the relationship between the subject of developmental courses taken and the likelihood of graduation? The findings for students that took developmental mathematics and developmental writing courses were significant and showed that students who took courses in these subject areas were less likely to graduate than students who did not take developmental education. The findings for the students that took developmental English and developmental reading courses were not significant and showed that students that took developmental courses in these subject areas were neither more nor less likely to graduate than students who did not take developmental education. 
To answer the research question a matched group of students who did and did not take each subject of developmental education courses (reading, English, mathematics, and writing) was utilized in a logistic regression model in which the primary independent variable was whether or not a student took each developmental education subject and the outcome variable was whether or not a student graduated with a bachelor's degree within six years. Of the total population $(17,168), 12,171$ students were matched. The matched group consisted of 8,912 students who did not take any developmental education courses and 3,390 students who took developmental education courses. The unmatched $\mathcal{L}_{1}$ statistic was .804 and matching resulted in an $\mathcal{L}_{1}$ of .618 for a 23 percent reduction in imbalance. These matched groups were utilized in a logistic regression model to determine the effect developmental education subject area had on a student's likelihood of graduation. Coefficients are expressed as exponentiated beta or odds ratios.

As mentioned above, examining the variables of interest, it can be seen that the coefficients for taking developmental courses in the area of math and writing are significant in that students who took developmental math and developmental writing courses were less likely to graduate than students who did not take developmental education. The coefficients for taking developmental courses in reading and English are not significant in that students who took developmental reading and developmental English courses were neither more nor less likely to graduate than students who did not take developmental education (see Table 22). The standard error for both students that took developmental reading and developmental English was high, 0.219 and 0.168 respectively. This high standard error is a result of the low sample size of students who took developmental reading and English. Whereas 3,852 students took developmental math (22.4\% of the total population) and 1,143 students took developmental 
writing ( $6.7 \%$ of the total population) only 279 students took developmental reading ( $1.6 \%$ of the total population and 504 students took developmental English (2.9\% of the total population). The low population numbers could explain why both taking developmental reading and English courses were not significant; i.e., students who took developmental reading and developmental English courses were neither more nor less likely to graduate than students who did not take developmental education. The Nagelkerke $\mathrm{R}^{2}$ for this model was 0.193 with 68.1 percent of cases assigned correctly. 
Table 22

Relationship Between the Subject of Developmental Courses Taken and the Likelihood of Graduation.

\begin{tabular}{|c|c|c|c|c|}
\hline \multirow{2}{*}{$\begin{array}{l}\text { Variables in the Equation } \\
\text { Background }\end{array}$} & \multirow[t]{2}{*}{$\operatorname{Exp}(B)$} & \multicolumn{2}{|l|}{ Sig. } & \multirow[t]{2}{*}{ S.E. } \\
\hline & & & & \\
\hline Male & 1.074 & 0.106 & & 0.044 \\
\hline African-American & 0.896 & 0.44 & & 0.142 \\
\hline In-State & 0.635 & 0 & $* *$ & 0.069 \\
\hline Economic Disadvantage & 0.693 & 0 & $* *$ & 0.046 \\
\hline \multicolumn{5}{|l|}{ Academic Preparation } \\
\hline High School GPA & 4.418 & 0 & $* *$ & 0.058 \\
\hline Composite ACT score & 0.993 & 0.462 & & 0.01 \\
\hline Late Enrollment & 0.51 & 0 & $* *$ & 0.187 \\
\hline Took Developmental Reading & 1.184 & 0.439 & & 0.219 \\
\hline Took Developmental Writing & 0.773 & 0.015 & $*$ & 0.105 \\
\hline Took Developmental English & 0.763 & 0.106 & & 0.168 \\
\hline Took Developmental Mathematics & 0.835 & 0 & $* *$ & 0.051 \\
\hline \multicolumn{5}{|l|}{ Institutional Context } \\
\hline Institution Percent Admitted & 1.015 & 0 & $* *$ & 0.003 \\
\hline Institution Percent Pell & 1.007 & 0 & $* *$ & 0.002 \\
\hline Institution Headcount & 1.017 & 0 & $* *$ & 0.004 \\
\hline Tuition and Fees & 0.766 & 0.036 & $*$ & 0.128 \\
\hline \multicolumn{5}{|l|}{ Financial Aid (in $\$ 1000$ s) } \\
\hline Academic grants and waivers & 1.07 & 0.116 & & 0.043 \\
\hline Athletic grants and waivers & 1.092 & 0 & $* *$ & 0.019 \\
\hline Other grants and waivers & 1.285 & 0 & $* *$ & 0.062 \\
\hline PROMISE scholarship & 1.118 & 0 & $* *$ & 0.021 \\
\hline State Need-Based Aid & 1.157 & 0 & $* *$ & 0.027 \\
\hline Federal Need-Based Aid & 0.87 & 0 & $* *$ & 0.016 \\
\hline Federal work study & 1.46 & 0 & $* *$ & 0.077 \\
\hline Subsidized loans & 0.991 & 0.607 & & 0.017 \\
\hline Unsubsidized loans & 0.994 & 0.67 & & 0.015 \\
\hline Constant & 0.005 & 0 & & 0.592 \\
\hline $\mathrm{R}^{2} \quad 0.193$ & & & & \\
\hline
\end{tabular}


Other variables were included in the analysis although they were not the variables of interest for research question five. The variables that were significant, and found to lessen the likelihood of the matched student group to graduate within six years included:

- Being an African-American student, a resident of West Virginia, economically disadvantaged, or a late enrollment student (not starting the fall semester after high school graduation);

- Attending an institution with higher tuition and fees; and

- Receiving federal need-based aid.

Variables that were found to be significant and increase the likelihood of the matched student group to graduate within six years included:

- Having a higher high school grade point average;

- Attending an institution that had a higher percentage of students admitted, a higher percentage of student enrollment, or a higher percentage of students receiving a Pell grant; and

- Receiving institutional athletic grants or waivers, other institutional grants or waivers, the PROMISE scholarship, state need-based aid, or federal work study.

\section{Research Question Six}

Research question six asked: Does time to degree differ between students who took developmental education courses and similar students who did not take any developmental courses? The findings for this question were significant and showed that among students who graduated, taking any developmental courses was associated with an increase of 0.848 terms to degree. 
To answer the research question a matched group of students who did and did not take developmental courses among those students who did graduate was utilized in an ordinary least squares regression model in which the primary independent variable was whether or not a student took developmental education and the outcome variable was the number of academic terms until degree completion. Of the total population $(17,168), 12,171$ students were matched. The matched group consisted of 8,912 students who did not take any developmental education courses and 3,390 students who took developmental education courses. The unmatched $\mathcal{L}_{1}$ statistic was .804 , and matching resulted in an $\mathcal{L}_{1}$ of .618 for a 23 percent reduction in imbalance. The matched groups were examined using linear regression analysis of time to degree for students who graduated with the dependent variable expressed as academic terms.

As was previously mentioned above, it can be seen that the coefficient for taking developmental courses was significant. Among students who graduated, taking any developmental course was associated with an increase of 0.848 terms to degree (see Table 23 ). Thus, for all students, taking developmental courses did not increase the likelihood of graduating and it does slightly increased the time to degree by one semester for those who do graduate. The adjusted $\mathrm{R}^{2}$ was 0.138 . The $\mathrm{R}^{2}$ is the square of the correlation between the model's predicted values and the actual values. This study uses the adjusted $\mathrm{R}^{2}$ because the student populations were clustered in universities and were this more similar with regard to race, age, economically disadvantaged, academic preparation, and the like. The adjusted $\mathrm{R}^{2}$ compensates for this clustering and shows how much of the variance in the outcome is attributed to the variables included in the study. 
Table 23

Time to Degree for Students Who Did and Did Not Take Developmental Courses.

\begin{tabular}{|c|c|c|c|c|}
\hline \multirow{2}{*}{$\begin{array}{l}\text { Matched Sample } \\
\text { Background }\end{array}$} & \multirow[t]{2}{*}{$\mathrm{B}$} & \multicolumn{2}{|c|}{ Sig. } & \multirow[t]{2}{*}{ Std. Error } \\
\hline & & & & \\
\hline Male & 0.579 & 0 & $* *$ & 0.058 \\
\hline African-American & 0.054 & 0.774 & & 0.188 \\
\hline In-State & 0.648 & 0 & ** & 0.094 \\
\hline Economic Disadvantage & 0.058 & 0.350 & & 0.062 \\
\hline \multicolumn{5}{|l|}{ Academic Preparation } \\
\hline High School GPA & -0.818 & 0 & ** & 0.078 \\
\hline Composite ACT score & 0.010 & 0.485 & & 0.014 \\
\hline Late Enrollment & 0.595 & 0.043 & * & 0.294 \\
\hline Took Developmental Education & 0.848 & 0 & $* *$ & 0.063 \\
\hline \multicolumn{5}{|l|}{ Institutional Context } \\
\hline Institution Percent Admitted & -0.018 & 0 & ** & 0.004 \\
\hline Institution Percent Pell & 0.002 & 0.305 & & 0.002 \\
\hline Institution Headcount & 0.022 & 0 & ** & 0.006 \\
\hline Tuition and Fees & 0.025 & 0.880 & & 0.168 \\
\hline \multicolumn{5}{|l|}{ Financial Aid (in \$1000) } \\
\hline Academic grants and waivers & -0.069 & 0.205 & & 0.054 \\
\hline Athletic grants and waivers & 0.026 & 0.199 & & 0.021 \\
\hline Other grants and waivers & 0.132 & 0.028 & $*$ & 0.060 \\
\hline PROMISE scholarship & -0.146 & 0 & $* *$ & 0.026 \\
\hline State Need-Based Aid & -0.087 & 0.014 & $*$ & 0.036 \\
\hline Federal Need-Based Aid & 0.077 & 0 & $* *$ & 0.021 \\
\hline Federal work study & -0.150 & 0.102 & & 0.092 \\
\hline Subsidized loans & 0.064 & 0.007 & $* *$ & 0.024 \\
\hline Unsubsidized loans & 0.060 & 0.002 & $* *$ & 0.020 \\
\hline Constant & 15.652 & 0 & & 0.795 \\
\hline Adjusted $\mathrm{R}^{2} \quad 0.138$ & & & & \\
\hline
\end{tabular}

Other variables were included in the analysis but were not the variables of interest for research question six, and do provide insight into areas that decrease and increase the time to degree attainment. The variables that were significant, and found to increase the time to degree attainment included: 
- Being a male student (0.579 semesters longer), a resident of West Virginia (0.648 semesters longer), or a late enrollment student (not starting the fall semester after high school graduation) (0.595 semesters longer);

- Attending an institution with a higher headcount (0.022 semesters longer); and

- Receiving institutional other grants and waivers (0.132 semesters longer), federal need-based aid (0.077 semesters longer), or subsidized and unsubsidized loans (0.064 and 0.060 semester longer respectively).

Variables that were found to be significant and decreased the time to earn a degree for the matched group of students included:

- Having one point higher on a high school grade point average upon admittance (0.818 semesters shorter);

- Attending an institution that had a higher percentage of students admitted (0.018 semesters shorter); and

- Receiving institutional academic grants or waivers (0.069 semesters shorter), state need-based aid ( 0.087 semesters shorter $)$, or federal work study ( 0.150 semesters shorter).

\section{Research Question Seven}

Research question seven asked: Does time to degree differ between students who took and passed developmental education courses and similar students who did not take any developmental courses? The findings were significant and showed that students who passed their developmental courses and graduated with a bachelor's degree within six years experienced an increase of 0.791 terms to degree. 
To answer the research question a matched group of students who took and passed developmental education courses and those who did not take developmental education courses among those who did graduate was utilized in an ordinary least squares regression model in which the primary independent variable was whether or not a student took and passed developmental education courses and the outcome variable was the number of academic terms until degree completion. Of the total population ( $\mathrm{N}=17,168), 11,063$ students were matched. The matched group consisted of 8,661 students who did not take any developmental education courses and 2,402 students who took developmental education. The unmatched $\mathcal{L}_{1}$ statistic was .814 and matching resulted in an $\mathcal{L}_{1}$ of .644 for a 21 percent reduction in imbalance. The matched groups were examined using linear regression analysis of time to degree for students who graduated and passed their developmental education courses.

As was mentioned above, the coefficient for taking developmental courses was significant. Among students who passed the developmental courses they took and graduated with a bachelor's degree within six years, taking any developmental courses was associated with an increase of 0.791 terms to degree (see Table 24). Thus, for students who passed their developmental education courses, taking developmental courses increased the time to degree for those who do graduate by nearly one semester. The adjusted $\mathrm{R}^{2}$ was 0.133 leaving much of the variance in time to degree likely explained by college progress and experience variables. 


\section{Table 24}

Time to Degree For Students Who Took and Passed Developmental Courses and Students Who Did Not Take Developmental Courses.

\begin{tabular}{|c|c|c|c|c|}
\hline Matched Sample & $\mathrm{B}$ & Sig. & & Std. Error \\
\hline \multicolumn{5}{|l|}{ Background } \\
\hline Male & 0.561 & 0 & $* *$ & 0.059 \\
\hline African-American & -0.046 & 0.824 & & 0.206 \\
\hline In-State & 0.507 & 0 & $* *$ & 0.098 \\
\hline Economic Disadvantage & 0.139 & 0.024 & $*$ & 0.061 \\
\hline \multicolumn{5}{|l|}{ Academic Preparation } \\
\hline High School GPA & -0.878 & 0 & ** & 0.081 \\
\hline Composite ACT score & -0.013 & 0.355 & & 0.014 \\
\hline Late Enrollment & 0.388 & 0.135 & & 0.259 \\
\hline Took Developmental Education & 0.791 & 0 & $* *$ & 0.065 \\
\hline \multicolumn{5}{|l|}{ Institutional Context } \\
\hline Institution Percent Admitted & -0.015 & 0 & ** & 0.004 \\
\hline Institution Percent Pell & -0.003 & 0.188 & & 0.002 \\
\hline Institution Headcount & 0.014 & 0.014 & $*$ & 0.006 \\
\hline Tuition and Fees & -0.057 & 0.736 & & 0.169 \\
\hline \multicolumn{5}{|l|}{ Financial Aid (in \$1000) } \\
\hline Academic grants and waivers & 0 & 0.996 & & 0.048 \\
\hline Athletic grants and waivers & 0.016 & 0.51 & & 0.024 \\
\hline Other grants and waivers & 0.079 & 0.218 & & 0.064 \\
\hline PROMISE scholarship & -0.058 & 0.022 & $*$ & 0.026 \\
\hline State Need-Based Aid & -0.051 & 0.15 & & 0.035 \\
\hline Federal Need-Based Aid & 0.006 & 0.767 & & 0.021 \\
\hline Federal work study & -0.057 & 0.552 & & 0.097 \\
\hline Subsidized loans & 0.087 & 0 & $* *$ & 0.024 \\
\hline Unsubsidized loans & 0.046 & 0.013 & $*$ & 0.018 \\
\hline Constant & 16.689 & 0 & & 0.8 \\
\hline Adjusted $\mathrm{R}^{2} \quad 0.133$ & & & & \\
\hline
\end{tabular}

Other variables were included in the analysis although they were not the variables of interest for research question seven. The variables that were significant, and found to increase the time to earn a degree for the matched group of students included: 
- Being a male student (0.561 semesters longer), a resident of West Virginia (0.507 semesters longer), or economically disadvantaged ( 0.139 semesters longer);

- Attending an institution with a higher headcount (0.014 semesters longer); and

- Receiving subsidized loans (0.087 semesters longer) or unsubsidized loans (0.046 semesters longer).

Variables that were found to be significant and decreased the time to earn a degree for the matched group of students included:

- Having a higher composite ACT score (0.013 semesters shorter);

- Attending an institution with a higher percentage of students admitted (0.015 semesters shorter) and with higher tuition and fees (0.057 semesters shorter); and

- Receiving the PROMISE scholarship (0.058 semesters shorter) or federal work study (0.057 semesters shorter).

\section{Summary}

The population of the study was 17,168 recent high school graduates who were full-time, first-time, first-year students at the ten public four-year public institutions in West Virginia in the 2002 and 2003 cohorts. To address the research questions for the study the population $(\mathrm{N}=$ $17,168)$ was divided into two groups - those students who took developmental education $(4,594$ students) and those students who did not take developmental education (12,574 students). The findings show that students who took developmental education courses were less likely to graduate than students who are similar and did not take developmental education courses. Students who took and passed developmental education courses were neither more nor less likely to graduate with a bachelor's degree within six years. Students that took developmental math and developmental writing courses were less likely to graduate within six years when 
compared to students who did not take developmental education. Students that took developmental reading and developmental English courses were neither more nor less likely to graduate within six years when compared to students who did not take developmental education. Students who graduated and took any developmental courses required an increase of 0.848 terms to degree, or took about one semester longer to graduate. Students who passed the developmental courses they took and graduated with a bachelor's degree within six years required an increase of 0.791 terms to degree, or took about one semester longer to graduate. 


\section{Chapter Five:}

\section{Summary, Conclusions, and Recommendations}

\section{Summary of the Study}

The purpose of the study was to determine the relationship between developmental education programs in West Virginia four-year higher education institutions and the success of the students in these programs as measured by bachelor's degree completion and the number of years required to complete the degree program. This dissertation focused on developmental education at West Virginia institutions of higher education, its effectiveness in leading to academic success and graduation, and any implications in terms of time that occur by adding these classes to a student's schedule. The population of the study was 17,168 recent high school graduates who were full-time, first-year students at the ten four-year public institutions in West Virginia in the 2002 and 2003 cohorts. To address the research questions for the study the population $(\mathrm{N}=17,168)$ was divided into two groups, those students who took developmental education (4,594 students) and those students who did not take developmental education (12,574 students).

This study provides descriptive statistics (frequency, mean, and proportions) on the demographic makeup and academic preparation level of first-year students taking remedial courses at public four-year institutions compared with students who do not take developmental courses. Descriptive statistics were also utilized to determine what proportions of students require remediation in the subject areas of reading, English, and mathematics.

As previously discussed, a controlled experiment for this study was not possible due to the non-randomized assignment of students in developmental education. Nor would creating a true experimental study be ethical. For this reason this study, like the instrumental variable 
approach used in Ohio (Bettinger \& Long, 2005) and the regression discontinuity approaches used in Florida and Texas (Calcagno \& Long, 2008; Martorell \& McFarlin, 2007), used quasiexperimental techniques to parse selection bias from program effects. Since multiple tests are used to determine developmental placement, and because full implementation of the West Virginia Higher Education Policy Commission policy on minimum scores was not immediate, there was no one clear cutoff score designating remedial placement. For this reason, regression discontinuity could not be used to address the issue of selection bias. This study addressed the issue of selection bias through implementing coarsened exact matching (CEM). Research questions three, four, five, six and seven were all answered using the quasi-experimental research technique of coarsened exact matching.

In these analyses, two different matching processes took place to assess the effects of two different conceptualizations of remediation. The first matching process created matched groups of those who participated in any developmental courses versus those who did not take any developmental courses. The second matching process created matched groups of those students who participated in and passed their developmental courses versus those students who did not take any developmental courses. These matched groups were utilized in a logistic regression model and linear regression analysis to determine the likelihood of graduation and the time to degree for students who took developmental education courses.

These analyses bring another set of recent state data to answer the question of whether developmental education is helping students in their pursuit of postsecondary degrees. This study adds to the growing list of rigorous state evaluations of developmental education programs. The findings of each of the research questions provide insight into the effectiveness of developmental education at West Virginia institutions of higher education. The data in the study 
suggest several issues that have been discussed in the current literature. The findings from this study both support and reject conclusions drawn from past research.

\section{Findings}

- Research Question One

Research question one examined the proportion of students who differed by race/ethnicity, sex, institution attended, economic disadvantaged status, residency status, whether or not they required remediation, high school grade point average, ACT scores, graduation rates, and time to degree. Of the total population $(\mathrm{N}=17,168), 4,594$ (26.8\% of the total population) students took developmental education. Of the total population that took developmental education, the majority of the population was white (89.6\%). The majority of this population that took developmental education courses was white, which is consistent with the findings of the total population where the majority of the population was white (92.6\%). Of these students, $44.1 \%$ of males and $55.9 \%$ of females were required to take developmental courses. This is not consistent with the findings from the population which was comprised of nearly half female (50.7\%) and half male (49.3\%) students and could suggest that females are underprepared for college and/or males are using other assessment measures to place out of developmental courses. Of the students who took developmental education, $45.5 \%$ were economically disadvantaged. This finding is higher than the proportion of students in the total population who were economically disadvantaged (23.8\%). This suggests that students who are economically disadvantaged are also at a disadvantage academically. Developmental education courses provide these students with the opportunity to gain access to four-year institutions of higher education. Of the population of students who require remediation, $82.9 \%$ were in-state students. This finding was consistent with the findings of the Editorial Projects in Education Research 
Center (2010) where West Virginia's educational system ranked below the national average in most of the academic categories and finished in the bottom half for student graduation. This suggests that students attending West Virginia high schools are not adequately prepared to complete college level work; also, students who enter into the inter-state postsecondary market are better prepared. Those students who were required to take developmental education had a grade point average of 3.03 and an 18.97 ACT score compared to 3.32 grade point average and a 22.85 ACT score for students who did not take developmental education. These findings were to be expected due to institutions of higher education using grade point average, ACT scores, and SAT scores to determine placement in remedial education (NCES $1996 \& 2003$ ). Of the population, $33.3 \%$ of the students who took developmental education graduated within six years and on average took 13.98 semesters to graduation compared to $56.8 \%$ of the students who did not take developmental education and graduated within six years, taking them an average of 12.61 semesters to graduation. Of those students who did graduate, students who took developmental education courses took approximately one term longer to do so. Examining these findings provides insight into some of the aspects that could be requiring students to take developmental education courses at West Virginia institutions of higher education.

\section{- Research Question Two}

Research question two examined the proportion of students who took different numbers of developmental classes and students in the developmental subject areas of mathematics, writing, reading, English, and basic skills. Some of the students required only one developmental class (29.2\%). However, in many cases the students who required developmental education took more than one developmental class $(70.8 \%)$. This suggests that if a student is deficient in one subject area, he or she is likely to be deficient in other areas as well. Also, it 
could be that students entering institutions are so deficient in a subject area that they require multiple courses in the same subject to be able to complete college level academic work. The majority of the students $(34.5 \%)$ in this study who were required to take more than one developmental course took two courses. The proportion of the students who took developmental education $(4,594$ students $)$ in the area of developmental math was $83.8 \%$, in developmental writing was $24.9 \%$, in developmental reading 6.1\%, in developmental English $10.9 \%$, and in developmental basic skills $41.1 \%$. The largest proportion of students $(83.8 \%)$ required remediation in developmental mathematics. This is consistent with previous research (NCES, 1996 \& 2003), and suggests that students attending West Virginia’s institutions of higher education are not receiving adequate preparation in their high schools to complete college level mathematics courses.

\section{- Research Question Three}

Research question three utilized a matched dataset to assess whether taking any developmental courses affected the likelihood of graduation. The findings were significant and indicated that, controlling for student background, academic preparation, institution attended, and financial aid received, taking developmental courses led to a lower likelihood of graduation.

The findings of research question three are inconsistent with the findings of Bettinger and Long (2005) who found that remedial education had a positive impact on the college outcomes of underprepared students. However, the findings of this research question were consistent with those of Martorell and McFarlin (2007) and Calcagno and Long (2008). Martorell and McFarlin (2007) found little support for the effectiveness of remediation, noting that remediation did not improve graduation outcomes of Texas students at both two-year and four-year institutions. However, Calcagno and Long (2008) found that, although remediation might promote early 
persistence in college by earning more total credits and by earning better college level math and reading grades, they did not translate to degree completion.

The findings for this research question were also similar to those of Attewell, Lavin, Domina, and Levey (2006) and Adelman (1996) who found that taking any remediation lessened the likelihood of graduation. This finding suggests that students taking developmental education led to a lower likelihood of graduation than those students who were not required to take developmental education courses.

- Research Question Four

Research question four utilized a matched dataset to assess whether taking any developmental courses and passing the courses they took influenced whether students graduate. The findings were not significant and indicated that, controlling for student background, academic preparation, institution attended, and financial aid received, taking developmental courses and passing those courses had no effect on the likelihood of graduating. Whereas simply taking developmental courses reduced likelihood of graduation, those who took and passed their developmental courses were neither more nor less likely to graduate with a bachelor's degree within six years.

This study, like that of Attewell, Lavin, Domina, and Levey (2006), examined institutions with different placement policies and sought to control for selection bias through a matching process. Also, like the Attewell et al. study, this study assessed the effect of students successfully completing their developmental courses. This study conceptualized student success in developmental courses as eventually passing courses in all developmental subjects taken. The findings of research question four are similar to the findings of Attewell et al. This study found 
that students who successfully passed reading and math courses did not have increased four-year degree completion rates.

Although the finding from this question was not significant and found that students passing the developmental courses they took provided no effect on graduation compared with similar students who did not take developmental courses, some conclusions can be drawn. The findings suggest that those students who receive the full treatment of developmental courses are not gaining an academic advantage from passing these classes. However, students who pass their developmental courses are experiencing similar results to those students who did not take developmental education. As a result, taking and passing developmental education courses does not translate to student success nor does it translate to student failure.

- Research Question Five

Research question five utilized a matched dataset to assess whether taking any subject of developmental courses impacted the likelihood of graduation. The findings for students that took developmental mathematics and developmental writing courses were significant and showed that students that took courses in these subject areas were less likely to graduate than students who did not take developmental education. The findings for the students that took developmental English and developmental reading courses were not significant and showed that students that took developmental courses in these subject areas were neither more nor less likely to graduate than students who did not take developmental education. As previously discussed in Chapter Four, the standard errors for the variables for taking developmental reading and developmental English were high, 0.219 and 0.168 respectively. These high standard errors are a result of the small number of students who took developmental reading and English. Conclusions about these 
findings cannot be drawn due to the likelihood of the results being skewed due to the low sample numbers.

This study is similar to the study conducted by Attewell, Lavin, Domina, and Levey (2006) which examined the effect of different subject areas of developmental education and their impact on the likelihood of graduation. Their study found that successfully completing reading or writing developmental courses, but not math, was associated with increased two-year completion, but not four-year completion. This study, unlike the Attewell et al. study, did not examine successful completion of developmental subjects. This study did assess the likelihood of graduation for students who took developmental education courses in specific courses. Similar to their findings, this study found that none of the developmental course subjects improved the likelihood of graduation for students attending a four-year institution.

\section{- Research Question Six}

To answer research question six a matched dataset was utilized to assess whether the time until degree completion for students who graduated was effected by taking any developmental education courses. The results indicate that, controlling for student background, academic preparation, institution attended, and financial aid received, taking developmental courses increased time to degree compared with similar students who did not take developmental education. Thus, for all students, taking developmental courses did not have a positive effect on the likelihood of graduating, but did slightly increase the time to degree for those who did graduate by nearly one semester.

The findings for research question six were significant and showed that students who took developmental education courses had increased time to degree completion. Students who required developmental education courses took 0.848 terms longer to graduate than students who 
were similar and did not take developmental education. This finding is consistent with Bettinger and Long's (2005) study that pointed out that increasing the number of requirements for students could extend the time to earn a degree and may negatively impact student outcomes such as persistence and major choice. Like the Bettinger and Long study, the findings from this study could be attributed to adding required courses that typically did not carry credit hours and did not count toward graduation. Also, adding any course that is not required for that student's program of study will increase the time to degree completion. These analyses may underestimate the effect of developmental education on time to degree because students were followed for only six years and students requiring several developmental courses may take even longer to graduate.

\section{- Research Question Seven}

The seventh research question utilized a matched dataset to assess whether the time to degree completion for students who graduated was effected by taking and passing developmental education courses. The results indicate that, controlling for student background, academic preparation, institution attended, and financial aid received, taking and passing developmental courses increased time to degree when compared with similar students who did not take developmental education. Thus, for students who passed their developmental education courses, taking developmental courses increased the time to degree for those who do graduate by nearly one semester.

The findings for research question seven were significant and showed that students who took and passed their developmental education courses increased their time to degree completion. These findings concur with Bettinger and Long (2005) that increasing the number of developmental course requirements for students could extend the time to earn a degree. Students who took and passed the developmental courses and graduated with a bachelor's degree 
within six years added 0.791 terms to a student's time to degree. Students who took and passed their developmental education courses and graduated had less of an increase in the number of academic terms to graduation than students who simply took developmental education courses on their way to graduation. These findings suggest that taking and passing developmental education courses does shorten the time to degree for students who require remediation. This could be attributed to these students not having to retake the same developmental education courses. Again, these analyses may underestimate the effect of developmental education because students were only followed for six years and students requiring several developmental courses may go even beyond this time window.

- Research Questions Three-Seven

This study included variables in the analysis, other than developmental education, that were not the variables of interest for the research questions. Although these variables were not directly related to the research questions, they do provide insight into other areas that impact the likelihood of graduation and the time to degree for students. Each of these factors was found to impact a student's educational outcome and should be considered when assessing the effectiveness of different educational services. The variables that were the same for each of the matched groups, were significant, and found to lessen the likelihood to graduate within six years for the student populations who simply took developmental education and who took and passed their developmental education courses included:

- Being a resident of West Virginia,

- Being economically disadvantaged,

- Being a late enrollment student (not starting the fall semester after high school graduation); and, 
- Attending an institution with higher tuition and fees.

Variables that were the same for each of the matched groups, were significant, and were found to increase the likelihood to graduate within six years for the student population who simply took developmental education and who took and passed their developmental education courses included:

- Having a higher high school grade point average;

- Attending an institution that had a higher percentage of students admitted,

- Attending an institution that had a higher percentage of students receiving a Pell grant,

- Receiving institutional athletic grants or waivers,

- Receiving state need-based aid; and,

- Receiving federal work study.

This study also included variables, other than developmental education, in the analysis that were not the variables of interest for the research questions and provide insight into areas that increased and decreased the time to degree attainment. The variables that were the same for each of the matched groups, were significant, and were found to increase the time to degree attainment for the student population who graduated and who simply took developmental education and who took and passed their developmental education courses included:

- Being a male student,

- Being a resident of West Virginia,

- Attending an institution with a higher enrollment,

- Receiving subsidized loans; and

- Receiving unsubsidized loans. 
Variables that were the same for each of the matched groups, found to be significant, and decreased the time to earn a degree for the student population who graduated and who simply took developmental education and who took and passed their developmental education courses included:

- Attending an institution that had a higher percentage of students admitted; and

- $\quad$ Receiving federal work study.

\section{Conclusions}

The findings of this study demonstrate the ineffectiveness of the developmental education system. Students who took developmental education courses were less likely to graduate than those students who did not take developmental education courses; and if the students did graduate, it took them about one semester longer to do so. This raises many questions about the developmental education programs, the resources spent on these programs, and the policies that require students to take these courses. As a result, steps need to be taken to reassess developmental education programs and develop a new plan for the future.

Although the results of the study suggest a bleak prospect for developmental education and its effectiveness at institutions of higher education, developmental education courses provide students who are in need of remediation the opportunity to obtain a college education, but not at the same success rate as those students not taking developmental education courses.

Developmental educational courses have allowed students of varying abilities and backgrounds to continue at institutions of higher education (Bettinger \& Long, 2005; Boylan, Bonham, \& White, 1999; Tierney \& Garcia, 2008). As this study shows, many of the students taking developmental education courses in West Virginia are economically disadvantaged and would not have the opportunity to attend institutions of higher education if not for developmental 
education courses. Advocates of developmental education offer rationales that are based on economic outcomes, societal benefits, and issues of fairness. Kozeracki (2002) cited a study by the Institute for Higher Education Policy (1998) that indicated that developmental education was less costly than sending an uneducated group into society which would lead to unemployment, low-wage jobs, welfare participation, and incarceration, whereas developmental education would lead to increased numbers of students who remained in college, earned a degree, and contribute to society. Calcagno and Long (2008) contend that one year of college, even without degree completion, has an educational return to the student. If these developmental students who completed their degree were denied admission to four-year institutions, many likely would never have completed their bachelor's degree because bachelor degree completion rates are lower for students who begin their postsecondary studies at two-year institutions.

Institutions of higher education are striving to raise student completion rates and increase degrees awarded due to concern from the federal and state governments. In West Virginia, graduation rates are one facet of the yearly Campus Compacts evaluations in which the West Virginia Higher Education Policy Commission assesses an institution's performance for the year. Institutions of higher education could increase completion rates by admitting only well prepared students. However, if institutions want to increase the number of degrees earned, concessions need to be made to admit and educate students who are less prepared to complete college-level work. As policymakers search for ways to incentivize degree completion, it is important to note that developmental education, although it is not yielding perfect outcomes, is still providing some students with the opportunity to complete their degree programs. These programs can help increase the numbers of degree earners as well as graduation rates for those students who need additional assistance to succeed academically. Furthermore, 33.3\% of the students included in 
this study who took developmental education graduated within six years. One-third of the students who are not ready to complete college level work were still able to complete their degree within six years with the assistance of developmental education programs. Only 56.8\% of all students who did not take developmental education graduated within six years. This suggests that other factors besides developmental education (e.g. economic status, prior high school performance, residency status, and the like) play an important role in the extent to which these students enter and succeed in college. It is also possible that the graduation rates might have been higher in this study if a time period of longer than six years had been used to measure success.

This study's findings differ from many of the findings of other state assessments of developmental education. As Martorell and McFarlin (2007) point out, the differences in findings across studies could be related to the actual quality and effectiveness of the remediation treatment in each state. The level of placement test score cutoffs and the autonomy schools have in developmental education policy as well could explain for the differences in the findings. Also, differences could arise from the population of students studied. Furthermore, each of the studies, including this study, used different research methods for determining the effectiveness of developmental education. This study used coarsened exact matching; Bettinger and Long (2005) used instrumental variable strategy and both Martorell and McFarlin, (2007) and Calcagno and Long (2008) used regression discontinuity. Each of these factors could explain the differences in the findings of recent state assessments of the effectiveness of developmental education.

Lastly, the incurred costs of developmental education are also a major concern to states, institutions, and students. Many students require loans to pay for their college classes and institutions are examining a way to decrease the cost to the student and to the institution. As a 
result, three-year bachelor programs are being implemented to decrease the time and resources spent on college. These programs require students to complete 120 credit hours to graduate instead of completing 128 credit hours. This heightens the concern of the effectiveness of developmental education courses. Taking developmental education courses adds to students' course loads, lengthens their time to degree, often times do not count for credit hours, and costs students additional money to take the course which increases their loan amounts. If these programs are deemed to be ineffective, institutions will begin to eliminate these programs and eliminate the opportunities for students who and underprepared for college to receive a degree. In the face of these changes, more research into the effectiveness of developmental education needs to be completed to find and implement effective programs to insure students who are in need of remediation are receiving the best opportunities to succeed while at college.

\section{Recommendations for Practice}

The observations, interpretations, and findings of this study provide insight into the effectiveness of developmental education which may shed light on future directions for improving developmental education programs. Each of these recommendations require federal and state policymakers, institutions of higher education, secondary education institutions, administrators, and educators to collaborate and work towards the common goal of student success. The following are recommendations for practice to improve student success in terms of degree attainment and time to degree:

- Efforts need to be made to increase the preparation of high school students so that they are ready to complete college-level work. Many students arrive at institutions of higher education with weak academic skills and are unable to complete college-level school work. These students are graduating from their high schools and are not prepared to be 
college students. Institutions of higher education need to work with high schools to reassess and or develop new guidelines for students to follow to prepare them for college. Policymakers must also develop new educational benchmarks that promote student learning and provide high school students with information they are expected to know when entering institutions of higher education. Currently, efforts at both the national and state levels are focused on trying to prepare students for college. The Diploma Project of Achieve, Inc. is tracking the progress of states by having college ready high school graduation requirements, by having standards based assessments in high schools, and by aligning these two concepts with college admissions standards. Also, efforts in West Virginia are focused on preparing students for college in the area of mathematics. Students who do poorly on the mathematics section of the WESTEST (the state's K-12 standardized assessment) are advised to take a specific mathematics course their senior year of high school to prepare them for college level mathematics courses.

- Creating assessment and placement standards for incoming freshmen students to institutions of higher education is an important step in assuring a student receives the educational training necessary for their success. The West Virginia Higher Education Policy Commission provided West Virginia institutions of higher education with placement standards which provided the means to "assure the integrity of the associate and baccalaureate degrees, to increase the retention and graduation rates of students, and to encourage high school students to improve their academic preparation for college" (WVHEPC, 2002, p. 1). Other states need to implement similar standards to provide a uniform set of guidelines for student placement at their colleges and 
universities. Also, these placement standards can provide insight into assessing the effectiveness of different placement instruments (e.g., ACT, COMPASS, and the like) so that one test could be used for developmental education placement.

- Institutions of higher education need to provide students in developmental education courses with information about the courses they are taking, the implications these courses have on their likelihood of graduation and their time to degree completion, and the effect of passing these courses has on their likelihood of graduation and time to degree completion. This information would demonstrate to students how succeeding in their developmental courses would lessen their time to degree and would provide them with a similar likelihood of graduation as those students who did not take developmental education courses. This would also lead educators and policymakers to focus their attention on how to best promote success in developmental education and to work to understand and implement the best practices to increase degree completion.

- Also, there are many concerns about the costs of developmental education to students, institutions, and to states. For students, developmental education courses typically do not carry credit that counts toward graduation and, as shown in this study, increases their time to degree. Again, given the relationship shown in this study between succeeding in developmental coursework and time to degree, it is important that students understand that passing these courses will lessen their time to graduate, which will in turn cost the student, the institution, and the state less.

- Finally, research needs to continue in the field of developmental education to gain an understanding in the effectiveness of these programs. This understanding would clarify 
student success patterns at institutions of higher education in terms of graduation and time to degree.

\section{Recommendations for Future Research}

This study assessed the effectiveness of developmental education at West Virginia institutions of higher education. This was achieved by examining the impact that developmental education courses had on student who took these courses and took and passed these courses. Due to the large pool of subjects, the findings presented here are representative of the student population at West Virginia institutions of higher education. Still, the importance of developmental education and the implications it has for future students demonstrate the critical need for continued serious, scholarly attention to this issue. The study conducted here provides a blueprint for future research in order to assess the effectiveness of developmental education statewide. Although the results from this study are useful, the following are recommendations for further research:

- A future study should assess the effectiveness of developmental education at other states' institutions of higher education. This study examined the students who attended the ten public four-year institutions of higher education in West Virginia.

- A study should also examine the effects of remediation at each of the individual institutions within the study. These findings would provide insight into what is and is not working at different institutions. This information could also assess if any institutions within the dataset yielded different results than what were found in this study and had improved the likelihood of graduation for students who took and took and passed their required developmental education courses. 
- A future study that looked at non-traditional students and/or adult learners could address the relationship between of students' absence from formal education and the effect developmental education has on persistence to graduation. This study examined only first-time, first-year college students who were recent high school graduates. Nontraditional students and/or adult learners form a substantial group of students who require developmental education and are an increasing population at many institutions of higher education. This study focused on students being underprepared to complete college level work when they leave high school. A future study of developmental education should explore the same variables utilized for this study to assess the effectiveness of developmental education for non-traditional students who are entering college several years after graduation from high school.

- Finally, a similar study, using a longer time frame than six years to determine the success through graduation rates should be completed and might provide different outcomes when assessing the effectiveness of developmental education. 


\section{References}

Abraham A. A. (1998). Discussant for "Remediation in higher education: Its extent and cost" by David Breneman. In D. Ravitch (Ed.), Brookings papers on education policy, (pp. 1-10). Washington, DC: The Brookings Institution.

Adelman, C. (1996). The truth about remedial work (point of view). The Chronicle of Higher Education, A56.

Aldridge, S. \& Rowley, J. (2001) Conducting a withdrawal survey, Quality in Higher Education, 7(1), 55-63.

Astin, A. (2000). An interview: Alexander W. Astin. National Crosstalk, 8(1), 2-3.

Attewell, P., Lavin, D., Domina, T., \& Levey, T. (2006). New evidence on college remediation. Journal of Higher Education, 77, 886-924.

Berliner, D. C., \& Biddle, B. J. (1995). The manufactured crisis: Myths, fraud, and attack on America's public schools. New York: Addison-Wesley-Longman.

Bettinger, E. P., \& Long, B. T. (2005). Addressing the needs of under-prepared college students: Does college remediation work? Cambridge: National Bureau of Economic Research. Working Paper No. 11325.

Bok, D. (2003). Universities in the marketplace: The commercialization of higher education, New Jersey: Princeton University Press.

Boyce, L. (2007). An Investigation of student characteristics' influence on retention at a two year proprietary career college. Unpublished Dissertation, West Virginia University, Morgantown, WV.

Boylan, H. R. (1988). The historical roots of developmental education. Research in Developmental Education, 5(3), 1-4. 
Boylan, H. R. (1999). Harvard symposium on developmental education: Demographics, outcomes, and activities. Journal of Developmental Education, 23(2), 2-4, 6, 8.

Boylan, H. R., \& Bonham, B. S. (2007). 30 Years of developmental education: A retrospective, Journal of Developmental Education 30(3), 2-4.

Boylan, H. R., Bonham, B. S., \& White, S. R. (1999). Developmental and remedial education in postsecondary education. New Directions for Higher Education, 108, 87-101.

Boylan, H. R., \& White, W. G. (1987). Educating all the nation's people: The historical roots of develop-mental education. Research in Developmental Education, 4(4), 1-4.

Breneman, D. W. (1998). Remediation in higher education: Its extent and costs. In D. Ravitch (Ed.), Brookings papers on education policy, (pp. 359-382). Washington, DC: The Brookings Institution.

Breneman, D., \& Haarlow, W. (1998). Remediation in higher education. Washington, DC: The Fordham Foundation.

Brier, E. (1984). Bridging the American preparation gap: An historical view. Journal of Developmental Education, 8(1), 2-5.

Brothen T., \& Wambach, C. (2004). The value of time limits on internet quizzes. Teaching of Psychology, 31, 62-64.

Calcagno, J. C., \& Long, B. T. (2008) The impact of postsecondary remediation using a regression discontinuity approach: Addressing endogenous sorting and noncompliance New York: National Center for Postsecondary Research. NCPR Working Paper.

Cohen, A. M. (1998). The shaping of American higher education. San Francisco, CA: Jossey Bass Publishers 
Editorial Projects in Education Research Center. (2010). West Virginia-State Highlights 2010. 4-18, Bethesda, MD: Author.

Fraser, J. (2001). The school in the United States. New York: McGraw Hill.

Grubb, N. (2001). From black box to pandora's box: Evaluating remedial/developmental education. Community College Research Center Brief, 11, 1-4.

Iacus, S. M., King, G., \& Porro, G. (2009). Causal inference without balance checking: Coarsened exact matching. Cambridge, MA: Institute for Quantitative Social Science, Harvard University, Working Paper.

Institute for Higher Education Policy (1998). The new millennium project on higher education costs, pricing, and productivity. Reaping the benefits: Defining the public and private value of going to college, Washington, DC: Author.

Jenkins, D., \& Boswell, K. (2002). State policies on community college remedial education: Findings from a national survey (National Survey No. CC-02-01): Education Commission of the States, Center for Community College Policy.

Jones, H, \& Richards-Smith, H. (1987). Historically black colleges and universities: A force in developmental education part II. Research in Developmental Education, 4(5), 7-9.

Kozeracki, C. (2000). Eric Review: Service-learning in the community college. Community College Review, 27, 54-70.

Kozeracki, C. (2002). Issues in developmental education. Community College Review, 29(4), 83-100.

Levin, H. M. \& Calcagno, J. C. (2008). Remediation in the community college. Community College Review, 35(3), 181-207. 
Levin, H. \& Koski, W. (1998). Administrative approaches to educational productivity. New Directions for Higher Education, 103, 9-21.

Lucas, C. J. (2006). American Higher Education: A History, $2^{\text {nd }}$ ed., New York: Palgrave Macmillan.

Martorell, F., \& McFarlin, I., Jr. (2007). Help or hindrance? The effects of college remediation on academic and labor market outcomes. Working Paper

McCabe, R. H. (2000). No one to waste: A report to public decision-makers and community college leaders. Washington, DC: Community College Press.

McCabe, R. H. (2003). Yes we can! A community college guide for developing America's underprepared. Phoenix, AZ: League for Innovation in the Community College.

McCabe, R. H., \& Day, P. (1998). Developmental education: A twenty-first century social and economic imperative. Mission Viejo, CA: League for Innovation in the Community College.

Mulvey, M. E. (2008). Under-prepared students: A continuing challenge for higher education. Research \& Teaching in Developmental Education, 24(2), 77-87.

National Commission on Excellence in Education. (1983). A nation at risk. Washington, DC: U.S. Government Printing Office.

Ohio Board of Regents (2001) Ohio Colleges and Universities 2001: Profile of Student Outcomes, Experiences and Campus Measures. Columbus, $\mathrm{OH}$ : Ohio Board of Regents.

Parks, N. W. (2001). The West Virginia Association for Developmental Education Annual Report, February 2001. West Virginia Association for Developmental Education. Fairmont State College, WV. 
Parsad, B., \& Lewis, L. (2003). Remedial education at degree-granting postsecondary institutions in fall 2000 (NCES Publication No, NCES 2004-010). Washington, DC: National Center for Education Statistics, U.S. Department of Education.

Payne, E.M., \& Lyman, B.G. (1996). Issues affecting the definition of developmental education. In J. L. Higbee \& P.L.Dwinell (Eds.), Defining developmental education: Theory, research and pedagogy. Carol Stream, IL: National Association for Developmental Education.

Preuss, M. (2008). Developmental education literature: A proposed architecture. Journal of Developmental Education, 32(2), 12-22.

Reynolds, C. L. \& DesJardins, S. L. (2009). The Use of Matching Methods in Higher Education Research: Answering Whether Attendance at a 2-Year Institution Results in Differences In Educational Attainment. In J.C. Smart (ed.), Higher Education: Handbook of Theory and Research. (24, pp. 47-97). New York: Agathon Press.

Roueche, J. E., Milliron, M. D., \& Roueche, S. D. (2003). Practical magic: On the front lines of teaching excellence. Washington, D.C: Community College Press.

Roueche, J. E., \& Roueche, S. D. (1993). Between a rock and a hard place: The at-risk student in the open-door college. Washington, DC: Community College Press.

Rosenbaum, P. R., \& Rubin, D. (1983). The central role of the propensity score in observational for causal effects. Biometrika, 70, 41-55.

Saxon, D. P., \& Boylan, H. R. (2001). The cost of remedial education in higher education. Journal of Developmental Education, 25(2), 2-4, 6, 8. 
Schmidt, P. (2006). Powerful forces draw academe into the fray: Economic fears and the high school-reform movement have colleges under pressure to help improve the education of children. The Chronicle of Higher Education, 52(27), B4.

Shaw, K. M. (1997). Remedial education as ideological battleground: Emerging remedial education policies in the community college. Educational Evaluation and Policy Analysis, 19, 284-296.

Snyder, T. (2001). Digest of education statistics, 2000 (NCES 2001-034). Washington, DC: U.S. Department of Education, National Center for Education Statistics.

Spellings, M. (2006), A test of leadership: Charting the future of U.S. higher education. Jessup, MD: U.S. Department of Education.

Stephens, D. (2001). Increasing access: Educating underprepared students in U. S. colleges and universities past, present, and future. Retrieved September 23, 2009, from East Tennessee State University Web site: http://faculty.etsu.edu/stephen/misc/increasingaccess.htm

Tierney, W. G., \& Garcia, L. D. (2008). Preparing underprepared students for college: Remedial education and early assessment programs. The Journal of At-Risk Issues, 14(2), 1-7.

Tinto, V., Goodsell, A., \& Russo, P. (1994). Building learning communities for new college students: A summary of research findings of the collaborative learning project. Syracuse University: National Center on Postsecondary Teaching, Learning and Assessment.

Urban, W., \& Wagoner, Jr., J. (2004). American education: A history. New York: McGraw Hill. U.S. Department of Education, National Center for Education Statistics (1996). Remedial Education at Higher Education Institutions in Fall 1995 (NCES 97-584). Washington, D.C.: U.S. Department of Education. 
U.S. Department of Education, National Center for Education Statistics (2003). Remedial Education at Degree-Granting Postsecondary Institutions in Fall 2000: Statistical Analysis Report (NCES 2004-010). Washington, D.C.: U.S. Department of Education.

U.S Department of Education, National Center for Education Statistics (2009). Digest of Educational Statistics, Appendix B: Definitions. Washington, D.C.: U.S. Department of Education.

Venezia, A., Callan, P. M., Finney, J. E., Kirst, M. W. \& Usdan, M. D. (2005). The governance divide: A report on a four-state study on improving college readiness and success. The National Center for Public Policy and Higher Education. National Center Report \#05-3

West Virginia Higher Education Policy Commission. (2002). Title 133: Procedural Rule West Virginia Higher Education Policy Commission Series 21. Freshman Assessment and Placement Standards. Charleston, WV: Author (WVHEPC).

West Virginia Higher Education Policy Commission. (2003). West Virginia Higher Education Report Card, 2003. Charleston, WV: Author (WVHEPC). 


\title{
Appendix A
}

\section{Data Agreement}

\author{
Blake Renner of West Virginia Universithe "ticensee") \\ wishes to obtain permission to use the Student Database of the West Virginia Higher Education Policy \\ Commission (WVHEPC) (the "Licensor ") for research purposes in accordance with the terms and \\ conditions herein described.
}

\section{Use of the Data}

(a) The Licensee will only use the data for research purposes to aid in the understanding of student access to and success in college.

(b) The Licensee may arrange, describe and analyze the data elements provided by WVHEPC but shall not change the data, nor misrepresent it in the presentation of research results. If incorporating data from other sources, the Licensee will clearly identify those data as coming from another source.

(c) The approval of WVHEPC to use the data in no way conveys any endorsement of the results or analysis. The Licensee shall not refer to WVHEPC for advertising or promotion purposes, except as specifically approved by the Commission.

Agreement of Nondisclosure

The Licensee agrees not to reveal any individually-identifiable student or employee information furnished by WVHEPC under the provisions of Section 183 of the Education Sciences Reform Act of 2002, Title V, subtitle A of the E-Government Act of 2002 (PL 107-279). Furthermore, the Licensee agrees not to make any disclosure or publication whereby a student or small group of students could be identified.

Review of Publications

(a) The Licensee has the right to publish results using the Database in accordance with the tenets of acceptable research practices.

(b) If the results of the Licensee contradict previous analysis reported by WVHEPC, the Licensee agrees to not publish those specific results without the approval of the Commission. In such an instance, WVHEPC agrees to work towards improving the accuracy of the indicator in future publications and editions of the Database.

\section{Protection of the Data}

This license is nontransferable, and the Licensee agrees not to distribute any portion of the data to other researchers, except for those under her direction, without the permission of WVHEPC. Any other parties working with the data under the Licensee's direction are subject to the same rules and regulations outlined in this document.

The Licensee shall take appropriate steps to prevent third parties from copying or publishing the data. This shall include:

- When not in use, the original extracts of the data will be physically secured from unauthorized access in a locked file cabinet in the Licensee's solitary and locked office.

- Any printed material containing individually identifiable information will also be secured from unauthorized access in the locked file cabinet in the Licensee's office.

- All versions of the data containing sensitive information will be maintained on a personal computer that is inaccessible to unauthorized users.

If the Licensee changes institutional affiliation, the Licensor should be notified and appropriate steps must be taken to ensure that the aforementioned conditions continue to be met.

Ownership of Data and Limited Liability

The Licensee acknowledges that the WVHEPC is the proprietor and owner of the Student Database. The Licensee shall take all appropriate steps to cite the source of the data by including on any research results 
Effectiveness of Developmental/Remedial Education

119

or portions) thereof, the following notice: "Source of Data: The West Virginia Higher Education Policy Commission Database."

Although WVHEPC is the owner of the data, it makes no warranty or representation and accepts no responsibility or liability in respect to any information contained in the Database or the application or arrangement of such information by the Licensee.

Complete Agreement

This agreement shall be deemed to be a contract made under the laws of West Virginia, and any related or supplemental documents and notices shall for all purposes be construed in accordance with and governed by the laws of such state.

This document contains the entire agreement and understanding between the parties and supersedes all prior agreements or understandings, whether written or oral, relating to all or any part of the undertakings set forth in this agreement. Amendments to this Agreement must be in writing, dated and signed by the parties, and the parties agree that an oral or implied waiver or modification cannot dispense with this requirement.

Purpose of Data Request (please use this space or attach additional materials):

Use HEPC student level data to assess the graduation outcomes of students who engage in developmental courses compared to those who do not take these course. Research will be used for his dissertation and any publications stemming from that work.

The Licenser:

West Virginia Higher Education Policy Commission 1018 Kanawha Boulevard, East, Suite 700

Charleston, West Virginia 25301

Fax: $304-558-4820$
The Licensee:

By:

Name: Blake J. Rennes

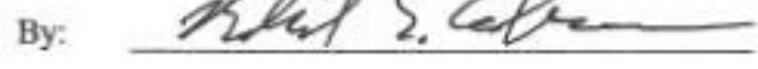

Name: Robert E Anderson

Title: Sr. Dir of Policy + Planing HEPC Title: Wu U Doc Can. Date:

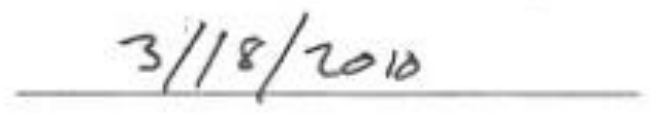

Date:

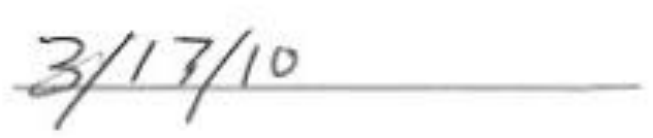

2 


\section{Appendix B \\ Email Confirmation of Not Human Subjects Research}

Subject: BRAAN2: IRB Protocol: Not Human Subjects Research

To: egoeres@mail.wvu.edu, Blake Jonathon Renner

Cc:

Bcc:

Date: 10/19/10 03:41 PM

From: wvuecomp@wvu.edu

Reply-To:

The following has been determined Not Human Subjects Research.

Tracking \#: H-22636

PI: Goeres, Ernest; Renner, Blake J.

Title: An Investigation of the Effectiveness of Developmental/Remedial Education at West Virginia Institutions of Higher Education

Determination Date: 10/19/2010 